\title{
Water-Based Therapies of Bhutan: Current Practices and the Recorded Clinical Evidence of Balneotherapy
}

\author{
Phurpa Wangchuk ${ }^{1, *,+}$, Karma Yeshi ${ }^{1,2,+}{ }^{(D}$, Karma Ugyen ${ }^{3}$, Jigme Dorji ${ }^{3}$, Karma Wangdi ${ }^{4}$, Samten ${ }^{5}$, \\ Phurba Tshering ${ }^{5}$ and Ari Satia Nugraha ${ }^{6}$
}

1 Centre for Biodiversity and Molecular, Development of Therapeutics, Australian Institute of Tropical Health and Medicine, Cairns Campus, James Cook University, Cairns, QLD 4870, Australia; karmayeshi@live.com

2 Sherubtse College, Royal University of Bhutan (RUB), Kanglung, Trashigang 42001, Bhutan

3 National Traditional Medicine Hospital (NTHM), Department of Traditional Medicine Services (DTMS), Ministry of Health, Kawajangsa, Thimphu 11001, Bhutan; jigmedorji707@gmail.com (K.U.); ugyensangay@gmail.com (J.D.)

4 Ugyen Wangchuck Institute for Conservation and Environmental Research (UWICER), Department of Forests and Park Services, Ministry of Agriculture and Forests, Lamai Goempa, Bumthang 32001, Bhutan; kwangdi@uwice.gov.bt

5 Menjong Sorig Pharmaceuticals Corporation Ltd., Kawajangsa, Thimphu 11001, Bhutan; samteny@yahoo.co.uk (S.); phurbatsher53@gmail.com (P.T.)

6 Drug Utilisation and Discovery Research Group, Faculty of Pharmacy, University of Jember, Jember 68121, Indonesia; arisatia@unej.ac.id

* Correspondence: phurpa.wangchuk@jcu.edu.au

+ Equally contributed as first authors.

Citation: Wangchuk, P.; Yeshi, K.; Ugyen, K.; Dorji, J.; Wangdi, K.; Samten; Tshering, P.; Nugraha, A.S. Water-Based Therapies of Bhutan: Current Practices and the Recorded Clinical Evidence of Balneotherapy. Water 2021, 13, 9 . https://dx.doi.org/10.3390/ w13010009

Received: 15 November 2020 Accepted: 18 December 2020 Published: 23 December 2020

Publisher's Note: MDPI stays neutral with regard to jurisdictional claims in published maps and institutional affiliations.

Copyright: $\odot 2020$ by the authors. Licensee MDPI, Basel, Switzerland. This article is an open access article distributed under the terms and conditions of the Creative Commons Attribution (CC BY) license (https:/ / creativecommons.org/ licenses/by/4.0/).

\begin{abstract}
Medical water therapy (also called medical hydrology) is practiced worldwide both for relaxation and treatment of diseases. While this practice is still thriving in Bhutan, there is a lack of proper documentation and critical study. Therefore, the current study reports on the water therapies practiced in Bhutan and their health benefits. We used four-stage process: (1) a review of literature on balneotherapy (both traditional textbooks and scientific papers); (2) listing and surveying the hot springs, mineral, and holy spring waters; (3) reviewing the health records of the patients maintained at the traditional hospitals and interviewing traditional physicians and patients about health benefits; and (4) reviewing available literature to identify existing clinical trials data to provide evidence for hydrotherapies. We found three main forms of hydrotherapies are practiced in Bhutan, which comprises herbal bath therapy, balneotherapy, and spiritually empowered waters. The most popular hydrotherapies are herbal bath and hot spring therapies. Herbal bath therapy needs traditional physicians' prescriptions, while hot springs do not require it. Through field surveys, ten different hot springs (tsha-chu) and 17 medicinal water or mineral springs (sman-chu), and 17 holy spring-waters (sgrub-chu) were identified. In general, medical water therapies are used by the Bhutanese people to treat various ailments, including gastritis, neurological disorders, arthritis, dermatological diseases, and rheumatological and musculoskeletal disorders. Even though a lack of scientific evidence makes it difficult to draw concrete conclusions on their traditionally claimed efficacy and safety, there are clinical evidences documented from other countries.
\end{abstract}

Keywords: hydrotherapy; balneotherapy; hot springs; herbal bath therapy; Bhutanese medicine

\section{Introduction}

Medical hydrology (MH) (often referred to as medical water therapy or hydrotherapy or hydropathy or water cure) is using water as a therapeutic medium in different physiochemical conditions to prevent and treat health problems [1]. For example, aquatic therapy uses physical exercise in regular water pools for relaxation, fitness, and physical rehabilitation [2]. Spa therapy uses either mineral water or thermal water infused with herbs, stone-heated water, and mud packs for relaxation and therapeutic purposes [3]. While crenotherapy 
uses mineral spring (fountain water) [1] for treating disorders, balneotherapy uses natural geothermal water or hot springs to alleviate symptoms of various pathologies including digestive disorders, urinary tract infections, and skin and rheumatic diseases [4]. Hot springs used in the balneotherapy have a temperature of at least $20^{\circ} \mathrm{C}$ and mineral content not less than $1 \mathrm{~g} / \mathrm{L}[2,5]$. Hot springs occur worldwide, but they are more common either in the active volcanic regions such as Japan, New Zealand, Iceland, or in places with plentiful groundwater such as the "Great Artesian Basin" in Australia and "Guarani Aquifer" in South America [6].

Some scholars argue that $\mathrm{MH}$ originated thousands of years ago in Asia, where Indians, Japanese, and Chinese first used water extract of tea and natural hot springs to purify their body and soul $[7,8]$. Others have noted that MH's practice stems from the Mediterranean Sea region, where they used mineral water for treating different health conditions. For example, it is recorded that Hippocrates (third century BC) recommended thermal baths to treat illnesses such as back and chest pains associated with pneumonia, respiratory problems, fatigue, headache, and joint problems [9]. Romans, Ottomans, and Central Europeans, and afterwards, the United States of America were pioneer countries to utilize water therapeutically in balneotherapy and spa therapy in the 1800s [10-12]. Around the turn of the nineteenth century, together with the recent explosion of the modern concept of body wellness, MH, especially spas, has progressively become an élite fashion in Europe and North Americas. As a result, it is not easy to distinguish between therapy and leisure. However, in many Asian countries, including China, the Tibetan regions of China, India, Japan, and Bhutan, $\mathrm{MH}$ is used as an alternative therapy and functions parallel with modern or allopathic medicine.

In Bhutan, MH comprises herbal bath therapy (herb-infused water or steam), balneotherapies (hot springs and mineral waters), and spiritually empowered waters. While herbal bath therapy is part of traditional health care services known as Bhutanese Sowa Rigpa medicine (BSM), the balneotherapies (hot spring and mineral water) and spiritually empowered water treatments are generally not part of BSM treatment regimens. Herbal bath therapy is considered the most popular treatment option amongst many other services provided by the BSM hospitals and Basic Health Units in the country. The Sowa Rigpa text called "Four Tantras" (Gyuzhi in Sowa Rigpa) [13,14], describes the indications, contraindications, medicinal benefits, and treatment procedures of herbal bath therapy. The famous Thangka set accompanying the "Blue Beryl" commentary to the "Four Tantras" [15] contains some procedures. Few publications outline their contemporary practices [16-18].

The BSM was officially integrated with the modern health care system in 1967, and subsequently, the government of Bhutan has considered quality, safety, and efficacy (QSE) as the foundation of this medical system [19]. It is arguable that BSM, including MH, would not have lasted more than thousands of years if it were not effective; nonetheless, a long clinical history does not substitute scientific evidence. In our continued efforts to improve QSE of BSM, we have previously conducted studies on herbal plants [20-22], zootherapy (treatment with animal-derived products) [23], and medical geology (treatment with mineral-derived products) [24]. However, there is not even a single comprehensive scientific literature about medical hydrology in Bhutan. Strong research programs are required at both the national and the clinic levels to foster better health policy, generate a scientific basis, and develop MH's medical standards.

This study is aimed to describe and document the therapeutic applications of various medical hydrology practiced in Bhutan. This step if considered the first step in developing parameters for QSE. At the present scenario of COVID 19 devastation, hydrotherapy practices requires better understanding of the nature and the location of water therapy areas, so that better monitoring, maintenance, and disinfection of the facilities can be effectively delivered. We have surveyed the water therapy areas, reviewed the traditional classical medical texts, evaluated the patient or visitor records, and performed meta-analysis of the available scientific literature. While this study has not taken experimental approaches towards evaluating $\mathrm{MH}^{\prime}$ s effects, the clinical trial data collected through a comprehensive 
literature review is expected to generate useful information on QSE associated with $\mathrm{MH}$. Since the Bhutanese terminologies (Wylie transliteration) are complex and difficult to understand (by the general readers), we used English translation first and provided Wylie in parentheses. A Supplementary Table S1 with detailed Wylie transliteration is provided for Tibetan and Bhutanese scholars.

\section{Materials and Methods}

\subsection{Study Areas}

Our study areas covered 11 out of 20 districts (Figure 1) in the country. Most of these study areas fall within Bhutan's protected areas, such as national parks and wildlife sanctuaries.

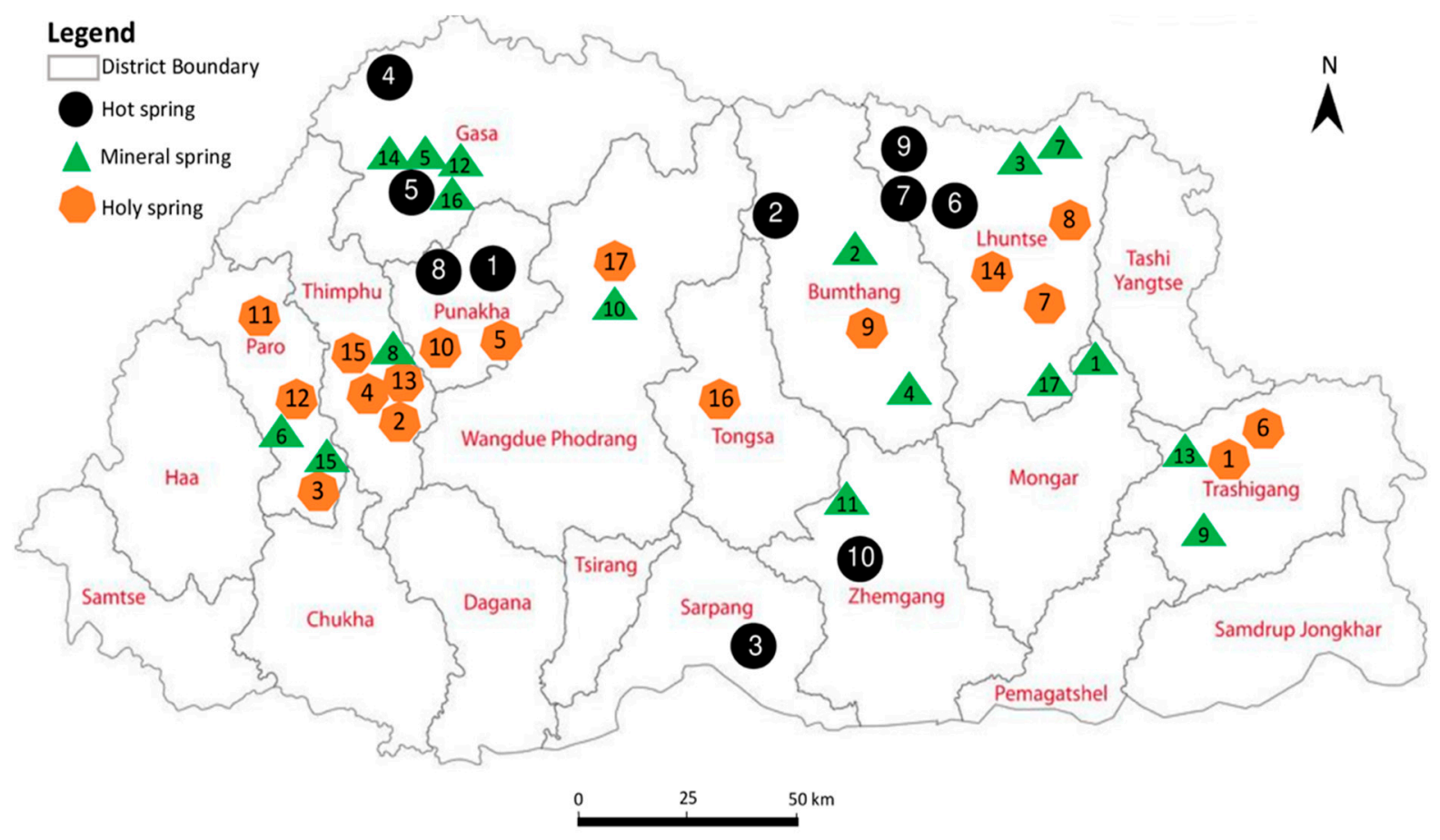

Figure 1. Map of Bhutan showing the distribution of 10 hot springs, 17 mineral springs, and 17 holy springs (sgrub-chu) recorded in this study. Numeric in the map indicates the location of hot springs, mineral springs, and holy springs, as indicated in the Tables 1, 2 and 3.

A total of 18 different locations under 11 districts covered in this study are listed below:

- $\quad$ Gasa (Gay za and Remey villages under Khamoed gewog) (2100-3826 masl)

- Punakha (Wolathang under Toedwang and Mitsegang under Goen Shari gewog (1737 masl)

- Wangdue Phodrang (Nobding under Dangchu gewog) (2355 masl)

- Thimphu (Kabisa under Kawang gewog) (2393 masl)

- Paro (Dobji dzong under Dokar gewog and Lunyi village under Lunyi gewog) (20802110 masl)

- Bumthang (Dur village and Zampa nyipa under Choekhor gewog) (3522-4795 masl)

- Lhuntse (gNey village under Gangzur gewog and Dungkar village under Kurtoe gewog) (2472-2761 masl)

- Mongar (Yarab village under Sershong gewog) (2513 masl)

- Trashigang (Donphangma under Khaling gewog and Rangjung under Radhi gewog) (870-2195 masl)

- Zhemgang (Duenmang hot spring under Nangkor gewog and Wangdigang under Trong gewog) (500-1533 masl) 


\section{- $\quad$ Sarpang (Sershong gewog) (332 masl)}

Except for a few places such as Lhuntse, Mongar, and Bumthang, hot springs (Tsha-chu) and mineral springs (sman-chu) are connected by motor roads in most districts. For example, the farthest hot spring from the motorable road access point was Dur hot spring, which is four days hike from Dur village in Choekhor gewog (gewog-administrative unit) under the Bumthang district.

\subsection{Study Design, Ethics, and the Data Collection Methods}

The current study is a review-guided observational study, described previously [25]. First, we reviewed classical Sowa Rigpa literature including Shelgong shelthreng [26], Four Tantras [13,14], and Khrungpe drimed shelgi melong [27] to generate a background knowledge on hot spring, mineral spring, holy water (sgrub-chu), mantra empowered water (sngags-chu) and herb-infused water called five Amritas herbal bath (bdud-rtsi lnga-lums). The review of literature such as classical text on Bhutan's hot springs and mineral springs [28] allowed us to select and prioritize locations of various hot springs and mineral springs based on their accessibility at the time of our survey. Second, we assessed the current literature on hot springs, mineral springs, and holy springs for recording an updated list of currently known practices in Bhutan. Third, we consulted the traditional physicians (Drung-tsho) and traditional clinicians (sman-pa) using open discussion forums after obtaining informed oral consent from them to authenticate the reviewed ethnomedicinal information. Fourth, several field trips were made to the selected study areas (18 localities under 11 districts) in 2006-2017 for field observations, photographing, sample collections, recording altitude, temperature, and therapeutic properties. We applied the convenience sampling methods to survey thermal, medicinal, and holy waters based on the villagers' oral accounts. The Traditional Medicine Research and Development Committee of Bhutan (TMRDB) reviewed and approved this study, and the administrator (Gup) of respective Gewogs (Blocks), which also arranged porter and ponies were consulted for surveying the research sites.

\subsection{Field Survey and Identification of Thermal, Medicinal, and Holy Spring Waters}

Based on the literature review and other information, the list and the locations of hot springs and mineral spring waters were produced. The altitudes were recorded using a hand-held Garmin Etrex GPS-Altimeter unit (Garmin Ltd., Olathe, KS, USA) and the digital photographs of the different hot springs, mineral springs, and holy springs were taken from the survey sites. Other standard data, including the environment surrounding the waters and locality names, were also recorded at each field site on pre-prepared forms. The identification and validation of therapeutic uses of respective hot spring and mineral spring were conducted by analyzing specific organoleptic properties such as smell, physical appearance, and color of each hot spring at its source as well as the stones around it, its temperature, and finally, the proximity of each subsidiary pool, if applicable. The temperature was recorded with the help of thermometer.

\subsection{Data Collection on Steam Bath Therapy and Holy Water and Analysis}

We formerly interviewed three traditional physicians dealing with herbal bath therapy at National Traditional Medicine Hospital (NTMH) in Thimphu on BSM concept of hydrotherapy. We randomly chose 25 patients availing herbal bath therapy at NTMH and interviewed informally to gain their perceptions about therapy and its benefits. The data on the frequency of patients' visits from the year 2018-2019 were retrieved from patients' daily register logbooks maintained at NTMH, Thimphu. The entire information gathered in this study were analyzed using MS Excel sheet and interpreted into tables and graphs.

\section{Results}

\subsection{Types and Classification of Healing Waters in Bhutan}

Based on the oral accounts of the people we interviewed, and the literature data collected in this study, we found that the healing water belong to three main categories: 
balneotherapies (hot springs and mineral spring water), herbal bath therapy (bdud-rtsi lnga-lums), and spiritually empowered water. Herbal bath therapy is one of the five physiotherapies (las-lnga dpyad-lnga) described in BSM, prepared from five medicinal plants. Hot springs are of two types: natural hot spring (rang-'byung chu-tshan) and artificial hot spring (bcos-ma'i chu-tshan). Natural hot springs are further classified into five types depending upon their mineral constituents: (i) hot spring rich in coal and sodium carbonate ( $r$ do-srol dang cong-zhi 'dres-pa las 'byung-ba), (ii) rich in coal and sulfur ( $r d o-s r o l$ dang mu-zi 'dres-pa las 'byung-ba), (iii) rich in coal and mineral pitch (rdo-srol dang brag-zhun 'dres-pa las 'byung-ba), (iv) rich in coal, sodium carbonate and sulfur (rdo-srolcong-zhi dang mu-zigsum 'dres-pa las 'byung-ba), and (v) rich in coal, sulfur, mineral pitch, and realgar (rdo-srol dang mu-zi brag-zhun ldong-rosbzhi 'dres-pa las 'byung-ba).

Similarly, mineral spring water is further categorized into five types, namely, mineral water that heals wind disorders (rlung sel-ba'i sman-chu), heals bile disorders (mkhris-pa sel-ba'i sman-chu), heals phlegm disorders (bad-kan sel-ba'i sman-chu), heals blood disorders (khrag sel-ba'i sman-chu), and heals wounds (chu-ser sel-ba'i sman-chu). Spiritually empowered or holy water includes spring water believed to be miraculously unearthed by enlightened beings or sages (sgrub-thobs), blessed rainwater (khrus-'bab-chu), sacred cleansing water (khrus-gsol-chu), mantra empowered water (sngags-chu), and ambrosia from the vase (bdud-rtsi bum-chu). While hot spring, mineral spring, holy spring, and blessed rainwater are natural in their origins, sacred cleansing water, mantra empowered water, ambrosia from the vase, and herb-infused water are prepared and empowered either through the addition of healing mantras (sngags kyi bnyen-pa) or through adding medicinal herbs or both.

\subsection{Herb-Infused Water (bdud-rtsi Inga-lums) Therapy}

The herb-infused water is often referred to as five Amritas or Elixir herbal mixtures bath. It is the fermented products (thang) of mainly five medicinal plants: Juniperus squamata, Rhododendron anthopogon, Ephedra gerardiana, Ajania nubigenum, and Myricaria rosea. This formulation contains an additional 26 minor ingredients. During this study, only Menjong Sorig Pharmaceuticals Corporation Ltd. in Thimphu was found to manufacture the five Amritas as per the BSM formulation and is thus not made by local healers. We found that the traditional physician prescribes the five Amritas formulation for paralysis, rheumatoid arthritis, acid peptic diseases, or bowel movement disorders (Table 1). The five Amritas is used as the main ingredient in herbal baths, herbal steaming (both localized and general), and herbal compress, which is discussed in the subsequent sections. We found that NTMH at Kawajangsa, Thimphu, currently practices four types of herbal bath therapies, namely, herbal bath immersion (chu-lums) (Figure 2a), steam bath (rlang-lums) (Figure 2b), localized steaming (rlang-dugs) (Figure 2c), and herbal compression (bcing-dugs) (Figure 2d). 


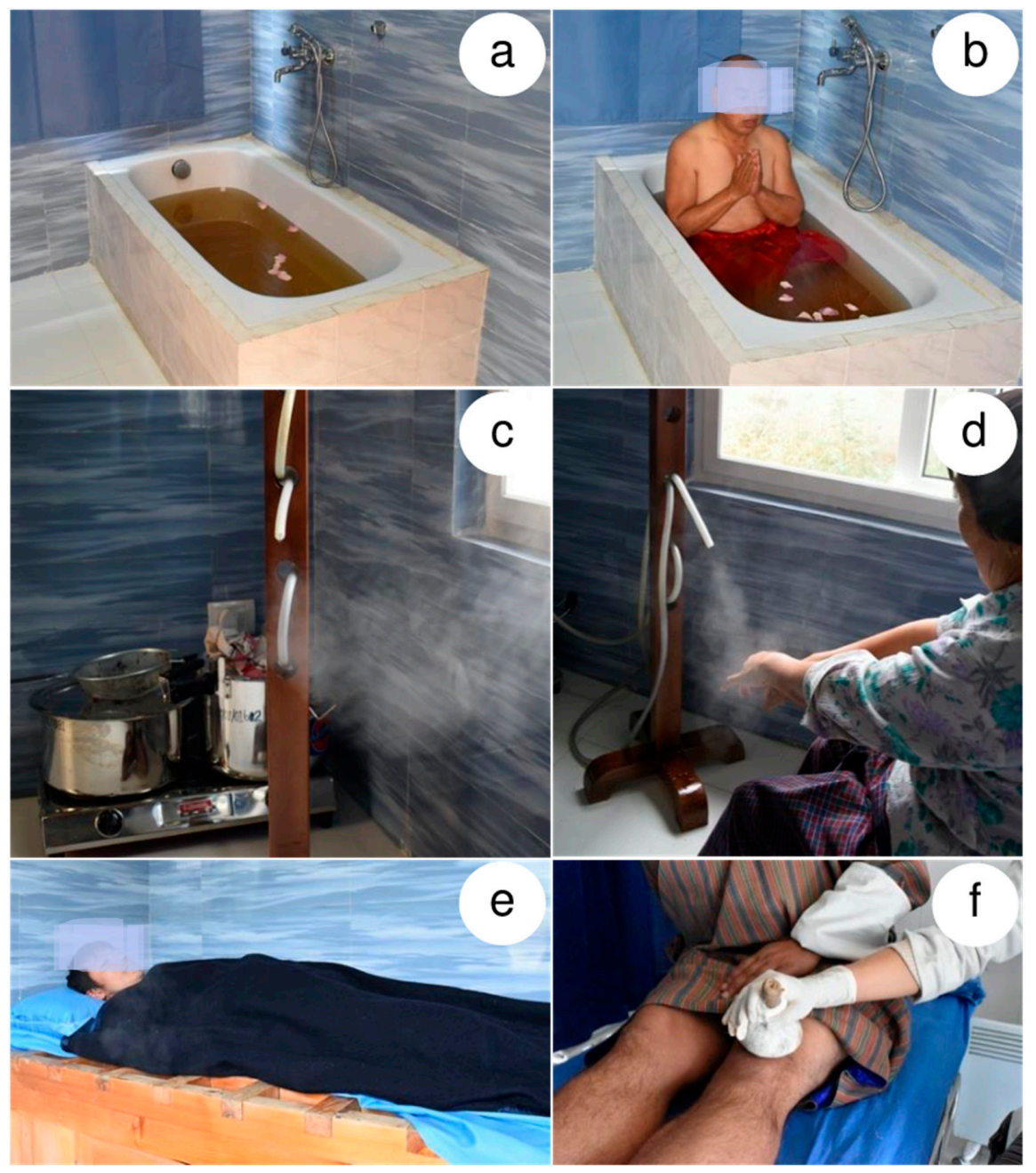

Figure 2. Herbal bath therapy practiced in Bhutan: (a,b) herbal immersion (chu-lums); (c,d) herbal steam bath (rlang-dugs); (e) Localized herbal steaming (rlang-lums); (f) herbal compression (bcing-dugs). (Courtesy: J. Dorji).

Table 1. Types of herbal bath therapy used in Bhutan for treating different types of diseases (for BSM Wylie transliteration refer Supplementary Table S1).

Types of Herbal Therapy Ethnopharmacological Uses

Used for treating gout, arthritis, neurological disorders, stiffness or paralysis of limbs, injury or illness affecting legs or foot, boil or tumor, large ulcer or sore, fresh and old wounds, stomach ulcer, swellings, hunchback or kyphosis, severe illness, dislocated disc, serous fluid accumulated between flesh and bone, and a sickness of cold character caused by phlegm and wind disorders.

Indicated for post-traumatic pain, swelling of hands and legs, neurological

Herbal steam bath disorder, muscular dystrophy, trembling, obstinate skin diseases, piles, chronic fever, gouts, arthritis, and rheumatism. It also provides relaxation to the stressful mind and body, and depression. It is also indicated for bile or phlegm disorders, and wind disorders.

Localized herbal steaming

Herbal compression
Same to steam bath.

Used for treating gout, arthritis, periarthritis, cervical spondylosis, varicose veins, psoriasis, sprain, sciatica, muscle dystrophy, obstinate skin diseases, spasm, gastritis, sinusitis, lower backache, paralysis, and trauma. 


\subsubsection{Herbal Bath Immersion (chu-lums)}

In herbal bath immersion therapy, we observed that the traditional physicians mix extract from five Amritas (usually five liters of the extract is the recommended volume) with $100 \mathrm{~L}$ of hot water, and then the patient remains immersed in the mixture (Figure 2a,b). Patients before immersing themselves in the bath (chu-lums) seek a thorough medical examination from a traditional physician. The bath temperature starts at $37^{\circ} \mathrm{C}$ (average body temperature), and then gradually increases to $45^{\circ} \mathrm{C}$. The temperature is again brought down to $37^{\circ} \mathrm{C}$ when a patient is about to come out of the bath. In a day, a patient can take a maximum of $30 \mathrm{~min}$ for the bathing. We found that an herbal bath is useful for at least 16 different types of ailments (Table 1). As per the data we obtained from patients register maintained in the medical record section at National Traditional Medicine Hospital, Thimphu, 4223 patients availed the service in 2019 (Figure 3).

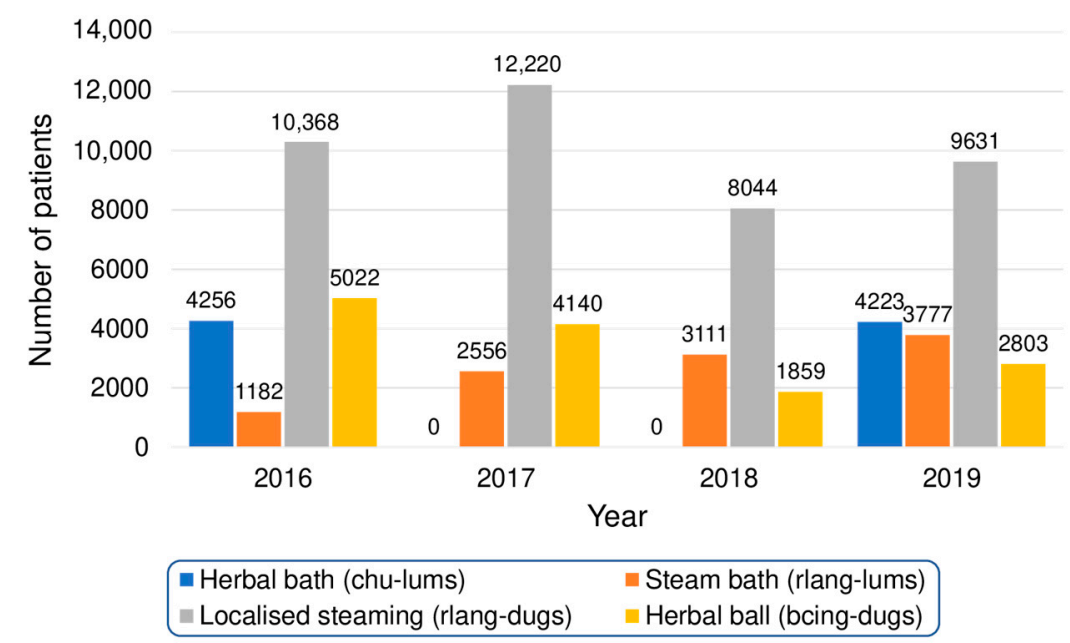

Figure 3. Number of patients treated by National Traditional Medicine Hospital in Thimphu using herbal bath therapy during the last four years (2016-2019).

\subsubsection{Steam Bath (rlang-dugs)}

In localized herbal steaming therapy, $50 \mathrm{gm}$ of five Amritas extract is mixed and boiled with three liters of water in a pressure cooker (Figure 2c). Subsequently, once the mixture is ready, the affected body part(s) of a patient is exposed to the pressure cooker's vapor via a sterile outlet for 15 to $20 \mathrm{~min}$ (Figure 2d). We observed that temperature is critical in this therapy. The traditional physicians that we interviewed said they never allow the temperature to exceed above $45^{\circ} \mathrm{C}$ since, beyond this, it could be disruptive, exceeding the physiological pain threshold, and lose its therapeutic values. The herbal steam bath applied to different points or parts of the patient's body with the heat accompanied by the herbal effect and moisture persuades perspiration, stimulating the skin for better circulation to keep all senses of humor in a harmonious state. The maximum number of patients availed localized herbal steaming among all four herbal bath related services containing five Amritas ingredient during the last four years. It has a similar therapeutic value to the herbal steam bath (Table 1).

\subsubsection{Herbal Steam Bath (rlang-lums)}

In herbal steam bath therapy, five Amritas herbal mixture is mixed with hot water in a 2:1 ratio $(v / v)$ in a wooden trough, and its steam or hot vapor is used for treating a patient (covered with clean blanket or towel for at least $30 \mathrm{~min}$ to get optimal benefits) (Figure 2e). Both herbal steam bath and localized herbal steaming therapies are known to treat about 10 different diseases (Table 1). The record maintained by NTMH showed that 10,626 availed herbal steam bath service in the past four years (2016-2019) with increasing trend every year (3777 patients treated in 2019) (Figure 3). 


\subsubsection{Herbal Compression (bcing-dugs)}

Unlike the other three types of therapies, we found that herbal compression is a straightforward method. Medicinal ingredients are wrapped inside a clean cloth bag or rag and then keep pressing against the patient's affected body parts (Figure 2f). According to traditional physicians in NTMH, the mainstream Sowa Rigpa medical system describes 30 different types of herbal compressions altogether, including 19 hot (tsha-sel) and 11 cold (grang-sel) therapies (often described as purgation therapy in Sowa Rigpa). However, NTMH currently practices only one of those types to treat about 15 different ailments and disorders. We found bcing-dugs is the second most popular herbal bath therapy, and 10,626 patients availed this therapy in the last four years (Figure 3).

\subsection{Balneotherapy}

\subsubsection{Hot Springs (tsha-chus) in Bhutan}

The current study found 10 hot springs with a total of 29 natural pools (Table 2), out of which only 26 pools are visited routinely by the people, including foreigners or tourists, for treating sinusitis, joint pain, indigestion, dyspepsia, urinary tract infection, skin infections, arthritis, headache, and migraine (Table 2). Other three hot springs, namely Laya hot spring and Wachi hot spring (under Gasa district in the North), and Yoenten Kuenjung hot spring (under Lhuntse district in the North-East) remain still unexplored. Of 29 pools, seven pools are in Dur hot spring in Choekhor gewog under Bumthang district (Central Bhutan), which is the highest amongst all the pools. Chuboog hot spring under Punakha district (Western Bhutan) and Yoenten Kuenjung hot spring under Lhuntse district (North-Eastern Bhutan) had the least water pools with two pools each. Among 10 hot springs, Chuboog hot spring (in Punakha district) (Figure 4a), Duenmang hot spring (in Zhemgang district) (Figure 4c), and Gasa hot spring (in Gasa district) (Figure 4e) are the three most popular hot springs in the country.

Balneologists generally classify hot springs based on temperature, mineral concentration, and $\mathrm{pH}$ values. In this study, we recorded the only temperature and classified hot spring based on their temperature (Table 2). Out of 29 pools from 10 hot spring, only six pools belong to the hot spring category (temperature, $>42^{\circ} \mathrm{C}$ ). While most pools, i.e., 18 pools, belong to warm springs (temperature, $35-42^{\circ} \mathrm{C}$ ) followed by two pools as tepid spring (temperature, $25-34^{\circ} \mathrm{C}$ ) and one pool as cold spring (temperature, $<25^{\circ} \mathrm{C}$ ). We found that traditional physicians and classical BSM texts [13,14] classify hot springs into five types based on mineral content. They are hot spring rich in sulfur nativum (mu-zi $i$ tsha-chu), hot spring rich in sulfur (mu-ljang gi tsha-chu), hot spring rich in lime (rdo-zho'i tsha-chu), water percolating from rocks (rdo-chu'i tsha-chu), and hot spring rich in calcite or carbonate mineral (cong-zhi'i tsha-chu). Additionally, depending upon different minerals in combination, hot springs can also be classified into 101 (chu-tshan brgya-rtsa) different types.

Out of 10 hot springs we surveyed, only two (Gasa hot spring and Gelephu hot spring) were accessible to motor road. The remaining hot springs were located at a few hours hike to as far as three days hike (e.g., Pasalum hot spring in Lhuntse). The most popular hot springs in Bhutan are: Chuboog hot spring in Punakha (Figure 4a); Koma hot spring in Lhuntse (Figure $4 \mathrm{~b}$ ); Duenmang hot spring in Zhemgang (Figure 4c); Khempajong gnye hot spring in Lhuntse (Figure 4d); Gasa hot spring in Gasa (Figure 4e); and Gelephu hot spring in Sarpang (Figure 4f). Chuboog hot spring in Punakha was visited most with 180 visitors on an average seasonally followed by Gasa hot spring, which was visited by 160 visitors in 2019. Gayza hot spring in Gasa ( 3 h hike from Laya village) and Yoenten Kuenjung hot spring in Lhuntse (2 days hike from gNey village) were the least visited hot spring with only six visitors on an average during the entire year. 


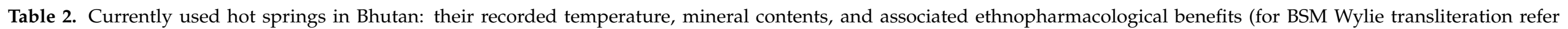
Supplementary Table S1).

\begin{tabular}{|c|c|c|c|c|c|c|c|}
\hline $\begin{array}{l}\text { Name of Hot } \\
\text { Spring }\end{array}$ & Pool No. & Pool Name & Location & Altitude (masl) & Temperature $\left({ }^{\circ} \mathrm{C}\right)$ & $\begin{array}{l}\text { Hot Spring } \\
\text { Category }\end{array}$ & Ethnopharmacological Benefits [28] \\
\hline \multirow{2}{*}{ Chuboog (1) } & 1 & Upper pool & \multirow{2}{*}{$\begin{array}{l}\text { Wolathang under } \\
\text { Toewang gewog, } \\
\text { Punakha }\end{array}$} & \multirow[b]{2}{*}{1737} & 39.9 & Warm spring & $\begin{array}{l}\text { Heals serous fluid associated with cold } \\
\text { disorders, which include urinary tract } \\
\text { infection and sexually transmitted } \\
\text { diseases (STDs). It also cures skin } \\
\text { diseases, chronic stomach-ache and other } \\
\text { diseases related to evil afflictions. }\end{array}$ \\
\hline & 2 & Lower pool & & & 43.5 & Hot spring & $\begin{array}{c}\text { Heals indigestion, cold disorders, } \\
\text { indigestion and increasing mucus } \\
\text { because of suppressed wind, and weak } \\
\text { and painful eyes. It is also useful against } \\
\text { stomach ailments, muscle sprains, } \\
\text { diabetes, and certain forms of phlegm } \\
\text { diseases. }\end{array}$ \\
\hline \multirow[b]{3}{*}{ Dur (2) } & 1 & $\begin{array}{c}\text { Chenrayzig } \\
\text { pool }\end{array}$ & \multirow{3}{*}{$\begin{array}{l}\text { Dur under } \\
\text { Choekhor gewog, } \\
\text { Bumthang }\end{array}$} & \multirow[b]{3}{*}{3522} & 40.2 & Warm spring & $\begin{array}{l}\text { Heals Indigestion and alleviates phlegm } \\
\text { diseases, dropsy, paralysis, poisonings, } \\
\text { neurological disorder, indigestion, and } \\
\text { vision effects. }\end{array}$ \\
\hline & 2 & $\begin{array}{l}\text { Zerkham } \\
\text { pool }\end{array}$ & & & 38.3 & Warm spring & $\begin{array}{l}\text { Heals phlegm diseases, paralysis, and } \\
\text { pustule, gout, rheumatoid arthritis, and } \\
\text { colic or spasm. }\end{array}$ \\
\hline & 3 & $\begin{array}{c}\text { Drangwa } \\
\text { mo pool }\end{array}$ & & & 42.0 & Warm spring & $\begin{array}{l}\text { Useful for treating cold disorder, } \\
\text { backache, and a woman's irregular } \\
\text { menstrual period. Additionally, heals } \\
\text { stomach pain and backache resulting } \\
\text { from phlegm disorders, STDs such as } \\
\text { syphilis and gonorrhea particularly for } \\
\text { females. }\end{array}$ \\
\hline
\end{tabular}


Table 2. Cont.

\begin{tabular}{|c|c|c|c|c|c|c|c|}
\hline $\begin{array}{l}\text { Name of Hot } \\
\text { Spring }\end{array}$ & Pool No. & Pool Name & Location & Altitude (masl) & Temperature $\left({ }^{\circ} \mathrm{C}\right)$ & $\begin{array}{l}\text { Hot Spring } \\
\text { Category }\end{array}$ & Ethnopharmacological Benefits [28] \\
\hline \multirow{4}{*}{ Dur (2) } & 4 & $\begin{array}{l}\text { Drangwa } \\
\text { pho pool }\end{array}$ & \multirow{4}{*}{$\begin{array}{l}\text { Dur under } \\
\text { Choekhor gewog, } \\
\text { Bumthang }\end{array}$} & \multirow{4}{*}{3522} & 43 & Hot spring & $\begin{array}{l}\text { Therapeutic properties are almost same } \\
\text { to Drangwa mo hot spring, but it is } \\
\text { beneficial more to males. Helpful in } \\
\text { treating stomach pain resulting from } \\
\text { phlegm disorders, heals kidney } \\
\text { disorders, alleviates urinary retention } \\
\text { caused by stones, cold rheumatism } \\
\text { affecting joints of the limbs, water } \\
\text { swelling diseases, swelling or edema, } \\
\text { and dropsy in the chest, arthritis, } \\
\text { indigestion, gastritis, and kidney } \\
\text { disorders. }\end{array}$ \\
\hline & 5 & Gunad pool & & & 43 & Hot spring & $\begin{array}{l}\text { Improves skin texture and glow and } \\
\text { assuage defective bile, wind disorders, } \\
\text { pain and swelling and wounds caused } \\
\text { by evil afflictions, chronic and acute } \\
\text { headaches. First bathing should be done } \\
\text { here and then continue to the rest. }\end{array}$ \\
\hline & 6 & Guru pool & & & 42.0 & Warm spring & $\begin{array}{l}\text { Useful for alleviating brown phlegm, } \\
\text { chronic fevers, rheumatism and gout, } \\
\text { pus, or serous fluid, and healing skin } \\
\text { diseases and malignant tumor. Locality } \\
\text { believes it has power to heal almost all } \\
\text { the diseases. }\end{array}$ \\
\hline & 7 & Badkan pool & & & 38 & Warm spring & Useful for phlegm disorders. \\
\hline
\end{tabular}


Table 2. Cont.

\begin{tabular}{|c|c|c|c|c|c|c|c|}
\hline $\begin{array}{l}\text { Name of Hot } \\
\text { Spring }\end{array}$ & Pool No. & Pool Name & Location & Altitude (masl) & Temperature $\left({ }^{\circ} \mathrm{C}\right)$ & $\begin{array}{l}\text { Hot Spring } \\
\text { Category }\end{array}$ & Ethnopharmacological Benefits [28] \\
\hline \multirow{4}{*}{ Gelephu (3) } & 1 & Pond 1 & \multirow{4}{*}{$\begin{array}{l}\text { Shershong gewog, } \\
\text { Sarpang }\end{array}$} & \multirow{4}{*}{332} & 34.0 & Tepid spring & $\begin{array}{l}\text { Heals serous fluid that results from cold, } \\
\text { swelling or edema, skin diseases, gout, } \\
\text { rheumatism, kidney disorders, and } \\
\text { phlegm disorders, hypertension, tumors, } \\
\text { conjunctivitis, dropsy, and chronic fever. }\end{array}$ \\
\hline & 2 & Pond 2 & & & 36.4 & Warm spring & Same as Pool 1. \\
\hline & 3 & Pond 3 & & & 38.1 & Warm spring & Same as Pool $1 \& 2$ \\
\hline & 4 & Pond 4 & & & Normal cool water & Cold spring & $\begin{array}{c}\text { Same as Pool 1, } 2 \text { \& } 3 \text { but rarely used, as } \\
\text { it is cold. }\end{array}$ \\
\hline Gayza (4) & & & $\begin{array}{l}\text { Gayza village } \\
\text { under Gayza } \\
\text { gewog, Gasa }\end{array}$ & 3826 & & NA & $\begin{array}{l}\text { Useful for people suffering from } \\
\text { poisoning, conjunctivitis, arthritis, and } \\
\text { inflammation. }\end{array}$ \\
\hline \multirow[b]{2}{*}{ Gasa (5) } & 1 & $\begin{array}{l}\text { Pond with } \\
\text { limestone }\end{array}$ & \multirow[b]{2}{*}{$\begin{array}{l}\text { Near bank of Mo } \\
\text { chu river, Gasa }\end{array}$} & \multirow[b]{2}{*}{2100} & 41.0 & Warm spring & $\begin{array}{l}\text { It is a general detoxifier for all poisons } \\
\text { and heals indigestion. It also helps to } \\
\text { assuage brown phlegm and phlegm } \\
\text { disorders indigestion and increasing } \\
\text { mucus because of suppressed wind. }\end{array}$ \\
\hline & 2 & $\begin{array}{l}\text { Pond with } \\
\text { sulfur } \\
\text { nativum }\end{array}$ & & & 40.50 & Warm spring & $\begin{array}{l}\text { Cures diseases caused by the } \\
\text { subterranean spirits called bhupati or } \\
\text { lord of earth which are usually } \\
\text { associated with festering wounds such as } \\
\text { leprosy. Additionally, useful for treating } \\
\text { unwanted serous fluid accumulation in } \\
\text { joints and lymph in the tissues. Improves } \\
\text { facial beauty, alleviates itching disorders, } \\
\text { large pustule, and large ulcer or sore. }\end{array}$ \\
\hline
\end{tabular}


Table 2. Cont.

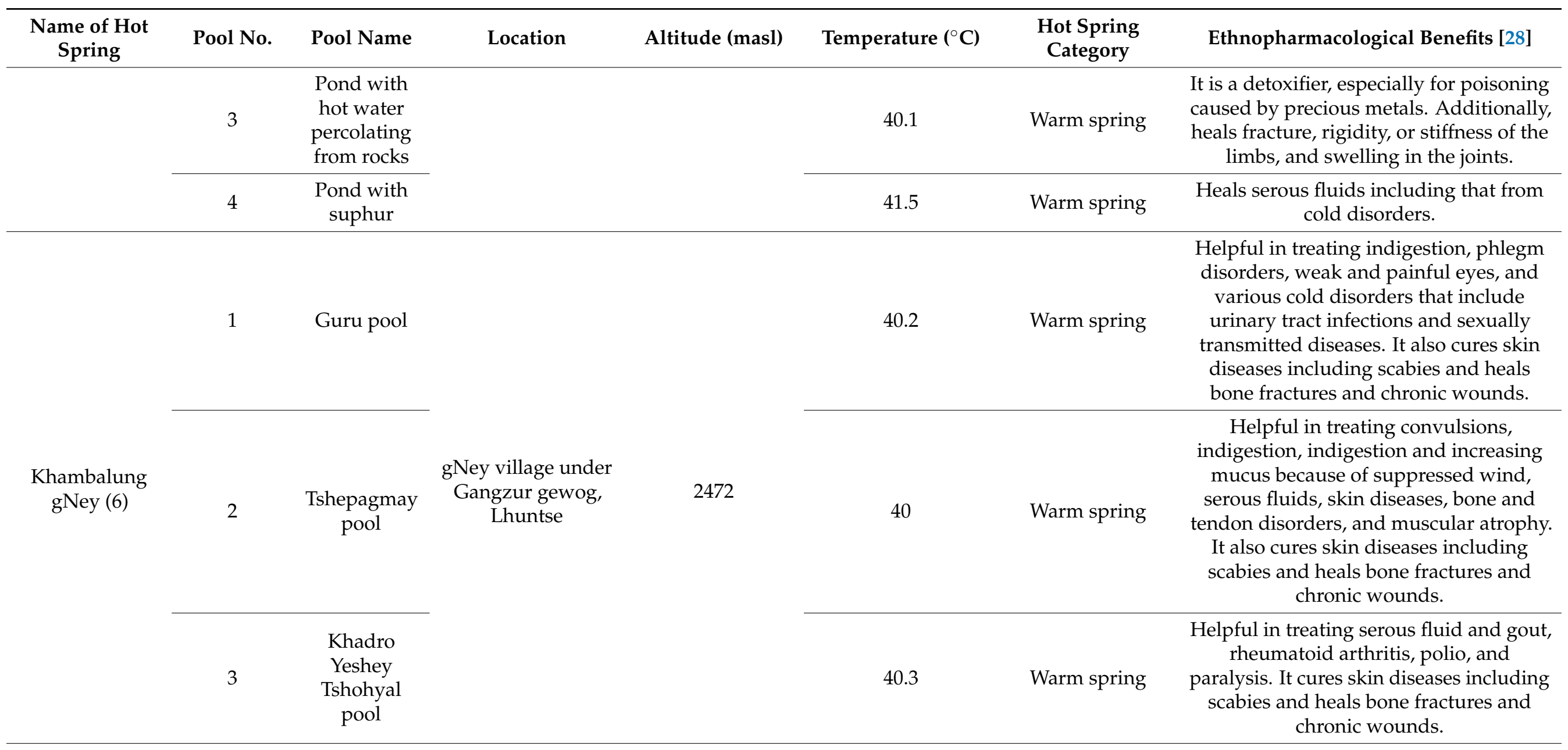


Table 2. Cont.

\begin{tabular}{|c|c|c|c|c|c|c|c|}
\hline $\begin{array}{l}\text { Name of Hot } \\
\text { Spring }\end{array}$ & Pool No. & Pool Name & Location & Altitude (masl) & Temperature $\left({ }^{\circ} \mathrm{C}\right)$ & $\begin{array}{l}\text { Hot Spring } \\
\text { Category }\end{array}$ & Ethnopharmacological Benefits [28] \\
\hline Pasalum (7) & & NA & $\begin{array}{l}\text { Gangzur gewog, } \\
\text { Lhuntse }\end{array}$ & 4795 & & & $\begin{array}{l}\text { Known to cure thirteen different diseases } \\
\text { and ailments. Useful against headache, } \\
\text { backache, and stomachache. }\end{array}$ \\
\hline \multirow{3}{*}{ Koma (8) } & 1 & Pool 1 & \multirow{3}{*}{$\begin{array}{l}\text { Near Tshori zam, } \\
\text { Punakha }\end{array}$} & \multirow{3}{*}{1839} & 38.3 & Warm spring & $\begin{array}{l}\text { Alleviates wind disorders, bile disorders } \\
\text { dizziness, defective bile, and } \\
\text { complicated convulsions, headache, and } \\
\text { lost vision. }\end{array}$ \\
\hline & 2 & Pool 2 & & & 33.20 & Tepid spring & $\begin{array}{l}\text { Heals skin diseases, indigestion, stiff } \\
\text { muscles, festering wounds, fractures, } \\
\text { serous fluids, increasing mucus because } \\
\text { of suppressed wind, swellings, inflicted } \\
\text { by evil spirits and combined disease of } \\
\text { defective wind and bile. }\end{array}$ \\
\hline & 3 & Pool 3 & & & 38.3 & Warm spring & $\begin{array}{l}\text { Good for joint pain, chronic tumor, and } \\
\text { anal fistula. }\end{array}$ \\
\hline \multirow{2}{*}{$\begin{array}{c}\text { Yoenten } \\
\text { Kuenjung (9) }\end{array}$} & 1 & Pool 1 & \multirow{2}{*}{$\begin{array}{l}\text { gNey village under } \\
\text { Gangzur gewog, } \\
\text { Lhuntse }\end{array}$} & \multirow[b]{2}{*}{2761} & NA & NA & Useful for memory disorders. \\
\hline & 2 & Pool 2 & & & NA & NA & $\begin{array}{l}\text { Used for bathing before dipping into } \\
\text { pool } 1 .\end{array}$ \\
\hline \multirow{2}{*}{ Duenmang (10) } & 1 & Pool 1 & \multirow{2}{*}{$\begin{array}{l}\text { On a steep cliff of } \\
\text { Kamjong under } \\
\text { Nangkor gewog, } \\
\text { Zhemgang }\end{array}$} & \multirow{2}{*}{500} & 40.7 & Warm spring & $\begin{array}{c}\text { Heals indigestion and improves the } \\
\text { bodily heat; phlegm disorders, gout or } \\
\text { feeling of lameness in the lambs. People } \\
\text { often visit this pool to cure goiters, joint } \\
\text { pain, sinusitis, skin diseases, headaches, } \\
\text { and tuberculosis. }\end{array}$ \\
\hline & 2 & Pool 2 & & & 45.2 & Hot spring & $\begin{array}{l}\text { Heals complicated convulsions, removes } \\
\text { bodily poisons, and alleviates both } \\
\text { chronic fevers, and feeling of lameness in } \\
\text { the lambs. }\end{array}$ \\
\hline
\end{tabular}


Table 2. Cont.

\begin{tabular}{|c|c|c|c|c|c|c|c|}
\hline $\begin{array}{l}\text { Name of Hot } \\
\text { Spring }\end{array}$ & Pool No. & Pool Name & Location & Altitude (masl) & Temperature $\left({ }^{\circ} \mathrm{C}\right)$ & $\begin{array}{c}\text { Hot Spring } \\
\text { Category }\end{array}$ & Ethnopharmacological Benefits [28] \\
\hline \multirow{2}{*}{ Duenmang (10) } & 3 & Pool 3 & \multirow{2}{*}{$\begin{array}{l}\text { On a steep cliff of } \\
\text { Kamjong under } \\
\text { Nangkor gewog, } \\
\text { Zhemgang }\end{array}$} & \multirow{2}{*}{500} & 49.0 & Hot spring & $\begin{array}{l}\text { Same source as Pool } 2 \text { and thus has same } \\
\text { medicinal properties, though people visit } \\
\text { to alleviate particularly headaches. }\end{array}$ \\
\hline & 4 & Pool 4 & & & 43.0 & Hot spring & $\begin{array}{c}\text { Same source as Pool } 2 \& 3 \text { and thus has } \\
\text { same medicinal properties, though } \\
\text { people visit it to heal particularly skin } \\
\text { diseases. }\end{array}$ \\
\hline
\end{tabular}

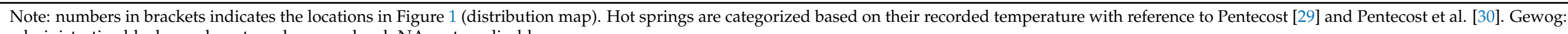
administrative block. masl: meters above sea level. NA: not applicable. 


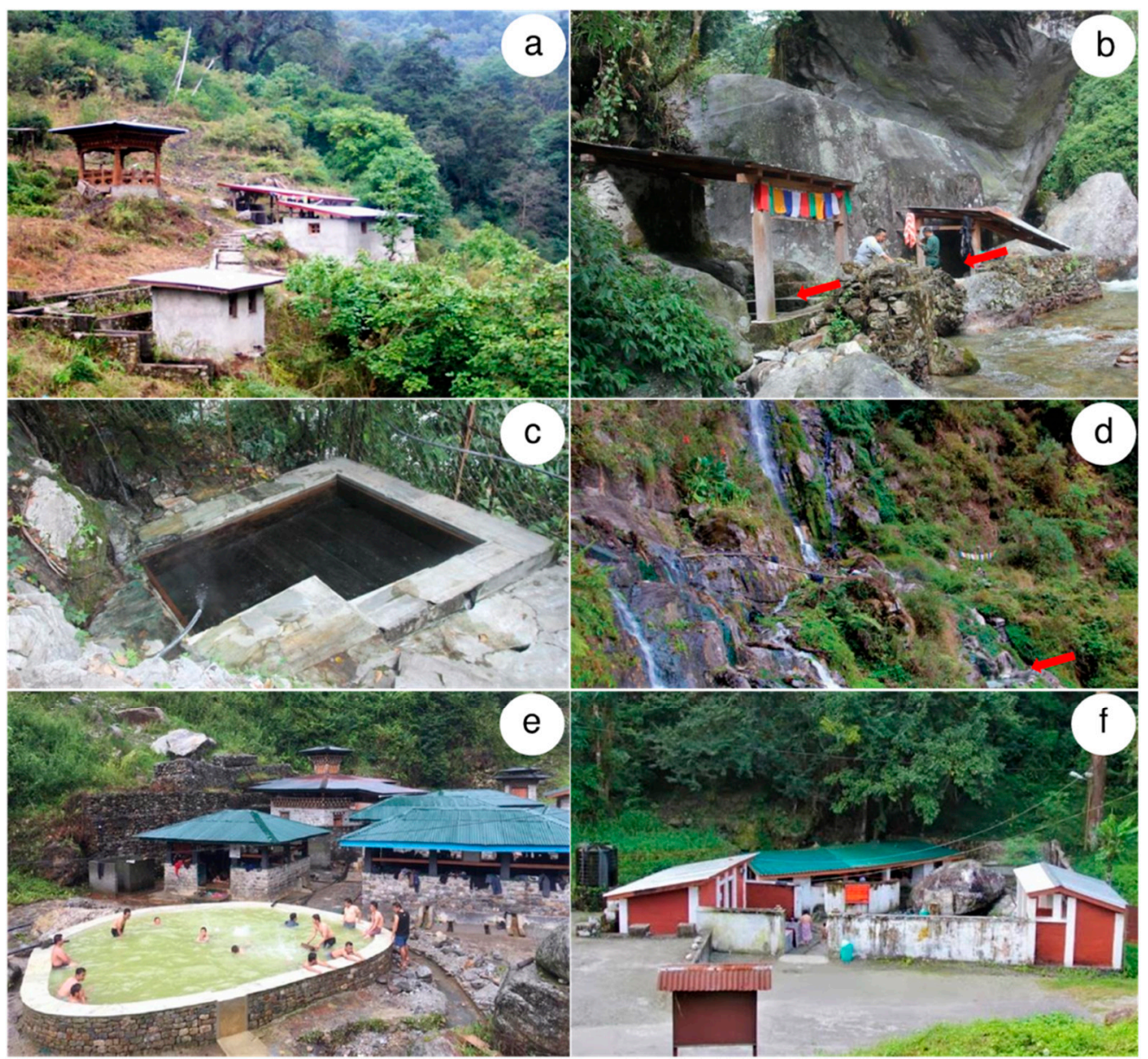

Figure 4. Popular hot springs in Bhutan: (a) Chuboog hot spring in Punakha; (b) Koma hot spring in Lhuntse; (c) Duenmang hot spring in Zhemgang; (d) Khempajong gNye hot spring in Lhuntse; (e) Gasa hot spring in Gasa; (f) Gelephu hot spring in Sarpang. Red arrow indicates the location of pool. (Courtesy: K. Yeshi \& K. Wangdi).

\subsubsection{Medicinal or Mineral Springs (sman-chu)}

The current study reports 17 mineral springs (Table 3), out of which most visited were those in the Gasa, Paro, Bumthang, and Thimphu districts. For instance, located just half an hour from Thimphu (capital city), the popular mineral spring water, Kabisa mineral spring, has been long used by the people for treating conditions such as migraine, headaches, sinusitis, stomach inflammation (ulcer), backache, fracture, sprain, joint pain, gout, arthritis, abscesses, and skin diseases. The site consists of wooden bathtubs. Many people (patients) camp near the site to ensure access to the mineral springs. We found that traditional physicians and BSM texts $[13,14]$ classify mineral springs into five main types exclusively based on diseases they can cure. These texts suggested that mineral or medicinal springs must contain either sulfur $(m u-z i)$, calcium carbonate (cong-zhi), mineral pitch (brag-zhun), iron oxide/limonite (sindhu-ra), or the mixture of these components (Table 3). The nature of the taste (specifically, sweet, sour, bitter, hot, and mixed flavors) and the healing properties of each mineral spring varies according to its chemical and mineral constituents. Most of the mineral springs identified in this study possess a rotten egg's characteristic smell. There is a belief among the Bhutanese that the stronger the smell, the better is its medicinal values. Its characteristic rotten egg's smell is linked to the hydrogen sulfide (colorless water-soluble gas). All mineral springs are cooling in nature and are usually associated with reddish brown or yellowish colored water sites/sources (Figure 5). It is equally popular as hot-spring and has many claimed medicinal benefits (Table 3). 
Table 3. Mineral/medicinal springs (sman-chu) in Bhutan and their ethnopharmacological properties (for BSM Wylie transliteration refer Supplementary Table S1).

\begin{tabular}{|c|c|c|c|c|}
\hline $\begin{array}{c}\text { Mineral Spring } \\
(\text { sman-chu) Names }\end{array}$ & Location & Altitude (masl) & Organoleptic Properties & Ethnopharmacological Uses \\
\hline Aja (1) & Serzhong gewog, Mongar & 2513 & NA & $\begin{array}{c}\text { Believed to cure } 18 \text { different types of diseases (nad-rigs } \\
\text { bco-rgyad in Sowa rigpa); useful for tuberculosis, body } \\
\text { aches, ulcers, and whooping cough. }\end{array}$ \\
\hline Baykan (2) & Choekor gewog, Bumthang & 3365 & Rock salt odor & Useful for phlegm disorders. \\
\hline Bharab (3) & Dungkar gewog, Lhuntse & 1770 & $\begin{array}{l}\text { Sweet and sour in taste. Has } \\
\text { Peacock feather color. }\end{array}$ & $\begin{array}{l}\text { Drinking it alleviates combined disease of wind and } \\
\text { defective bile, arthritis, body aches, and tuberculosis, } \\
\text { and maternity sickness. }\end{array}$ \\
\hline Draagchu (4) & Ura Gewog, Bumthang & 3090 & NA & $\begin{array}{l}\text { Useful for arthritis, stomach-aches, skin diseases, and } \\
\text { eye disorders. }\end{array}$ \\
\hline Bjagay (5) & Khatoe Gewog, Gasa & 2316 & Sour in taste. Light in nature. & $\begin{array}{l}\text { Alleviates phlegm and bile disorders, arthritis, and } \\
\text { joint pains. }\end{array}$ \\
\hline Bjagay (6) & Lunyi gewog, Paro & 2110 & NA & $\begin{array}{l}\text { Useful for fractures, ulcers, cardiac diseases, physical } \\
\text { wounds, and arthritis. }\end{array}$ \\
\hline Kabisa (8) & Kawang gewog, Thimphu & 2393 & $\begin{array}{l}\text { Sour and sweet in taste. } \\
\text { Darkish in color and heavy } \\
\text { in nature. }\end{array}$ & $\begin{array}{c}\text { Stir and inhaling the vapor can alleviate defective bile } \\
\text { and wind disorders, joint pains, and stomach-aches. It } \\
\text { can also heal complications developed after delivery } \\
\text { in women. }\end{array}$ \\
\hline Dhonphangma (9) & Khaling gewog, Trashigang & 2195 & NA & Useful for dizziness and headaches. \\
\hline Dangchu-Wangchu (10) & $\begin{array}{l}\text { Dangchu gewog, Wangdue } \\
\text { phodrang }\end{array}$ & 2355 & $\begin{array}{l}\text { Sweet and sour in taste. Sky } \\
\text { blue in color. }\end{array}$ & $\begin{array}{l}\text { Believed to be useful for } 13 \text { different types of disease } \\
\text { (nad-rigs bcu-gsum in Sowa rigpa). Useful for general } \\
\text { disorders since it is considered as a detoxifier. }\end{array}$ \\
\hline Dangkhar (11) & Wangdigang, Zhemgang & 1533 & NA & $\begin{array}{l}\text { Useful against headaches, hemorrhoids, tetanus, } \\
\text { swollen limbs, joint pains, and ulcers. }\end{array}$ \\
\hline
\end{tabular}


Table 3.

Cont.

\begin{tabular}{|c|c|c|c|c|}
\hline $\begin{array}{c}\text { Mineral Spring } \\
\text { (sman-chu) Names }\end{array}$ & Location & Altitude (masl) & Organoleptic Properties & Ethnopharmacological Uses \\
\hline Loyee (12) & Khatoe gewog, Gasa & 2666 & $\begin{array}{l}\text { Sweet and sour in taste. } \\
\text { Inhabited by green algae. It is } \\
\text { viscous and heavy in nature. }\end{array}$ & $\begin{array}{l}\text { Drinking it progresses good sleep. Bathing with it } \\
\text { moisturizes and soften the skin. It heals wind } \\
\text { disorders, asthma, and tuberculosis inside lungs. }\end{array}$ \\
\hline Khabtey (13) & Trashigang & 870 & NA & $\begin{array}{l}\text { Useful for joint pains, backaches, fever, arthritis, and } \\
\text { tuberculosis. }\end{array}$ \\
\hline Tokay (14) & Khatoe gewog, Gasa & 2518 & Sour in taste, light in nature. & $\begin{array}{l}\text { Heals phlegm, headache, and blood disorders, } \\
\text { gastritis, headaches, and stomach-aches. }\end{array}$ \\
\hline Dobji or Milarepa's (15) & Dokar gewog, Paro & 2080 & $\begin{array}{l}\text { Taste like normal drinking } \\
\text { water }\end{array}$ & $\begin{array}{l}\text { It can heal fractures, disease induced by cold, } \\
\text { dyspepsia, blood pressure, backache, urinary tract } \\
\text { infections, cancer, food poisoning, ulcers, diabetes, } \\
\text { and cancer. }\end{array}$ \\
\hline Mage-phenday (16) & Khatoe Gewog, Gasa & 2666 & NA & $\begin{array}{l}\text { Cures sore infections, inflamed wounds, and other } \\
\text { skin diseases. }\end{array}$ \\
\hline
\end{tabular}

Note: numbers inside the brackets indicates the locations of sman-chus in the Figure 1 (distribution map). masl: meters above sea level. NA: not applicable. 


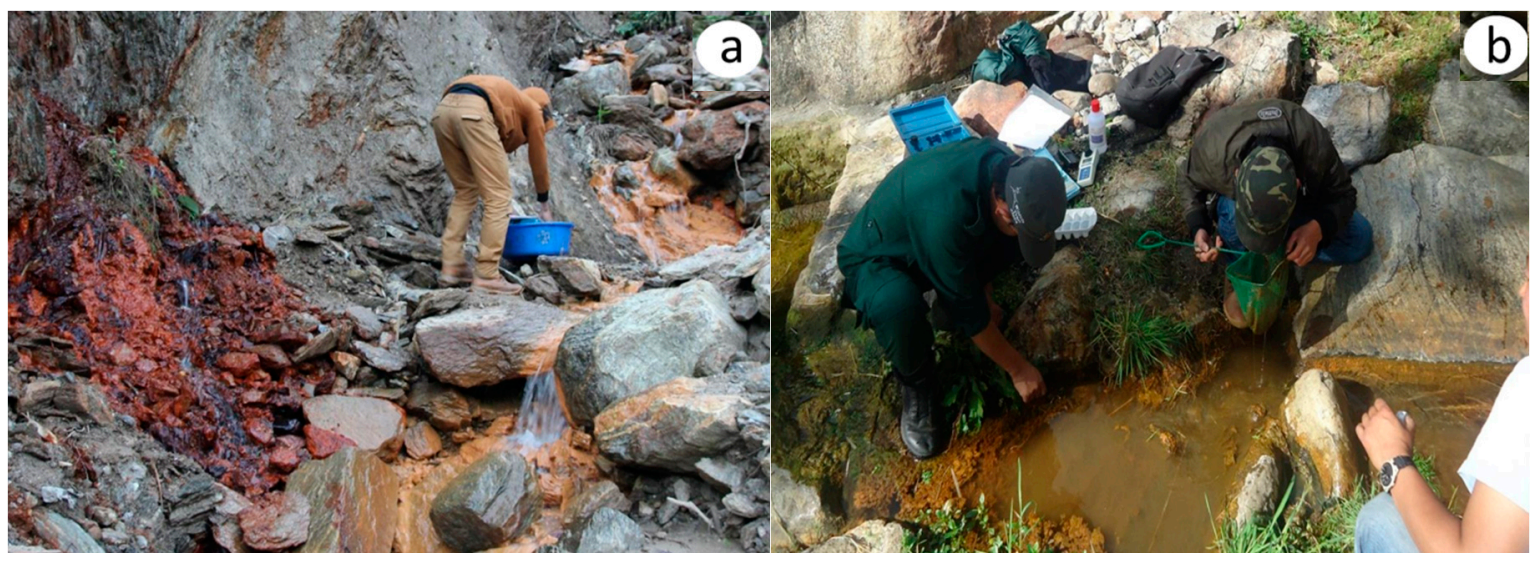

Figure 5. Representative mineral spring waters (sman-chu) in Bhutan: (a) Khabtey mineral spring water in Trashigang; (b) Study team assessing Bharab mineral spring water in Lhuntse. (Courtesy: K. Wangdi).

\subsubsection{Holy Spring Waters (Sgrub-chu)}

There are many holy water sources distributed all over Bhutan. In this study, we have documented only 17 of them and their associated therapeutic properties (Table 4). They are considered the most popular and spiritually significant spring waters. Holy water is a perennial water source, seeping out from underneath the ground or trickling down a cliff. Regardless of the season, the volume or flow of water remains consistent and unchanged. A common folk belief is that holy water emerges from the ground due to the asceticism and blessings of Buddhas and Bodhisattvas. According to the study participants, holy waters are unearthed by some great saints or sages (who are compassionate and may have attained enlightenment) in drought-stricken villages (lack of water supplies) afflicted by the deadly disease, or in places of legendary and sacred temples. Therefore, almost all holy waters reported in the current study are associated with spiritual or sacred sites (gnas). Thus, Bhutanese believe that holy water is very sacred that it can cleanse one's sins (sdig-pa) and defilements (sgrib). Holy water possesses both purging and healing powers.

Some holy waters are associated with many spiritual as well as medicinal benefits. For instance, the Tsheringma holy water of Tshangkha village in Trongsa district (Figure 6) is believed to have been established by the deity of longevity (goddess-tshe-ring-ma) and thus, drinking or bathing in it is believed to enhance one's longevity. This holy water is sought to treat throat-related disorders, and the Bhutanese believe that this spring water can progress melodious voice, a quality usually desired by singers. Some study participants said that people from Tshangkha village who live nearby the Tsheringma holy water have a particularly melodious voice since it is their primary source of drinking water. The Dobdrek holy water of Dobji Dzong was unearthed by a Tibetan Saint, Jetsun Milarepa (1040-1123), and residents nearby believe that its origin is Druk Ralung in the Western Tibetan region of China. In addition to cleansing sins and defilements, nearby communities firmly believe that this holy water heals stomach inflammation, headache, wounds, tumor, warts, and blood pressure. It is also used as tonic water. Another healing water of Bartsham in the east (under Trashigang district), but one not necessarily holy water, is Jomorichu, said to have been established and blessed by Ama Jomo (deity of a lake, which is also considered nor-lha). The people of Bartsham and Biddung villages use it against tumors, headaches, and general ailments. 
Table 4. Holy springs (sgrub-chu) in Bhutan and their ethnopharmacological properties.

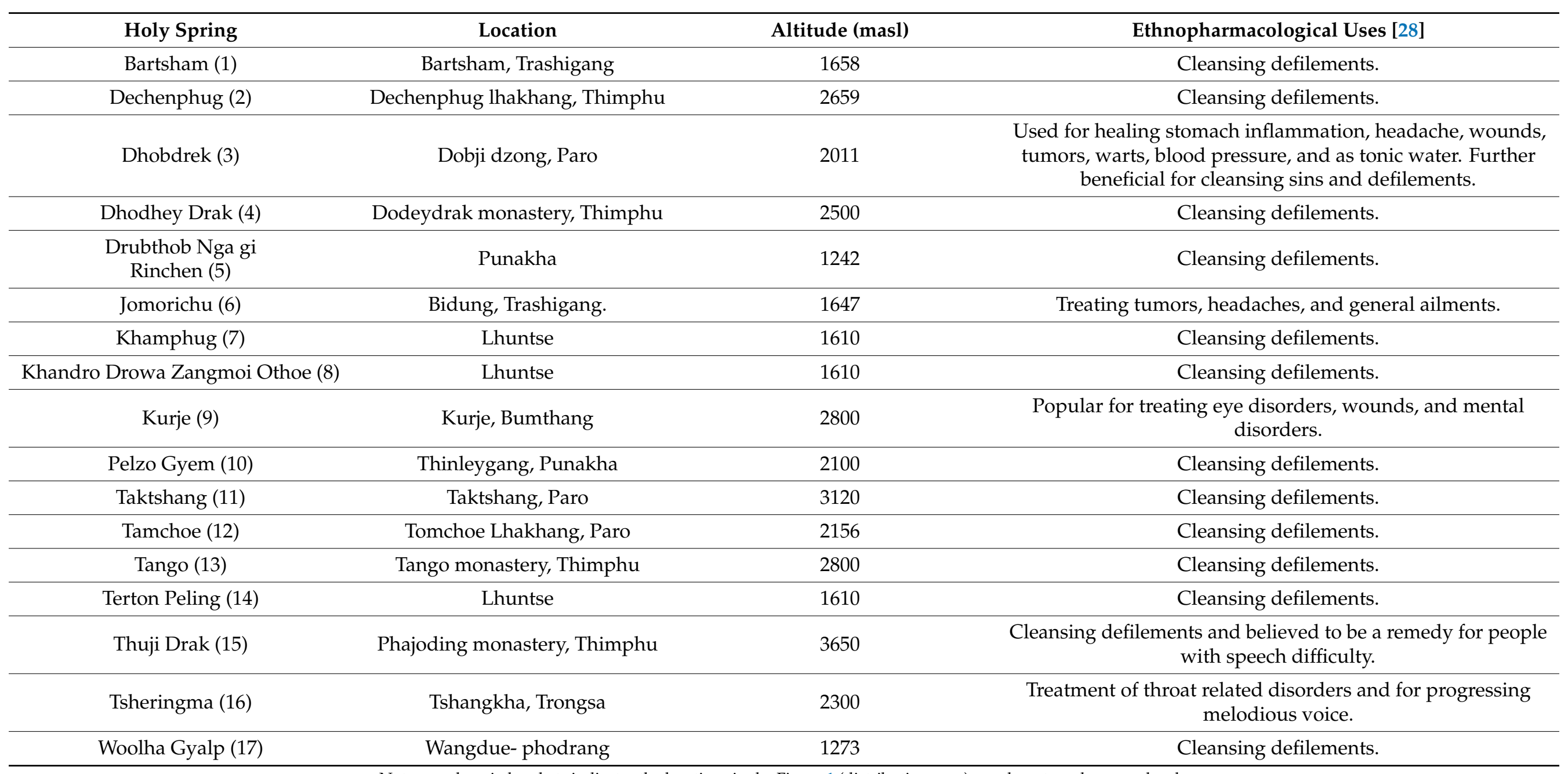




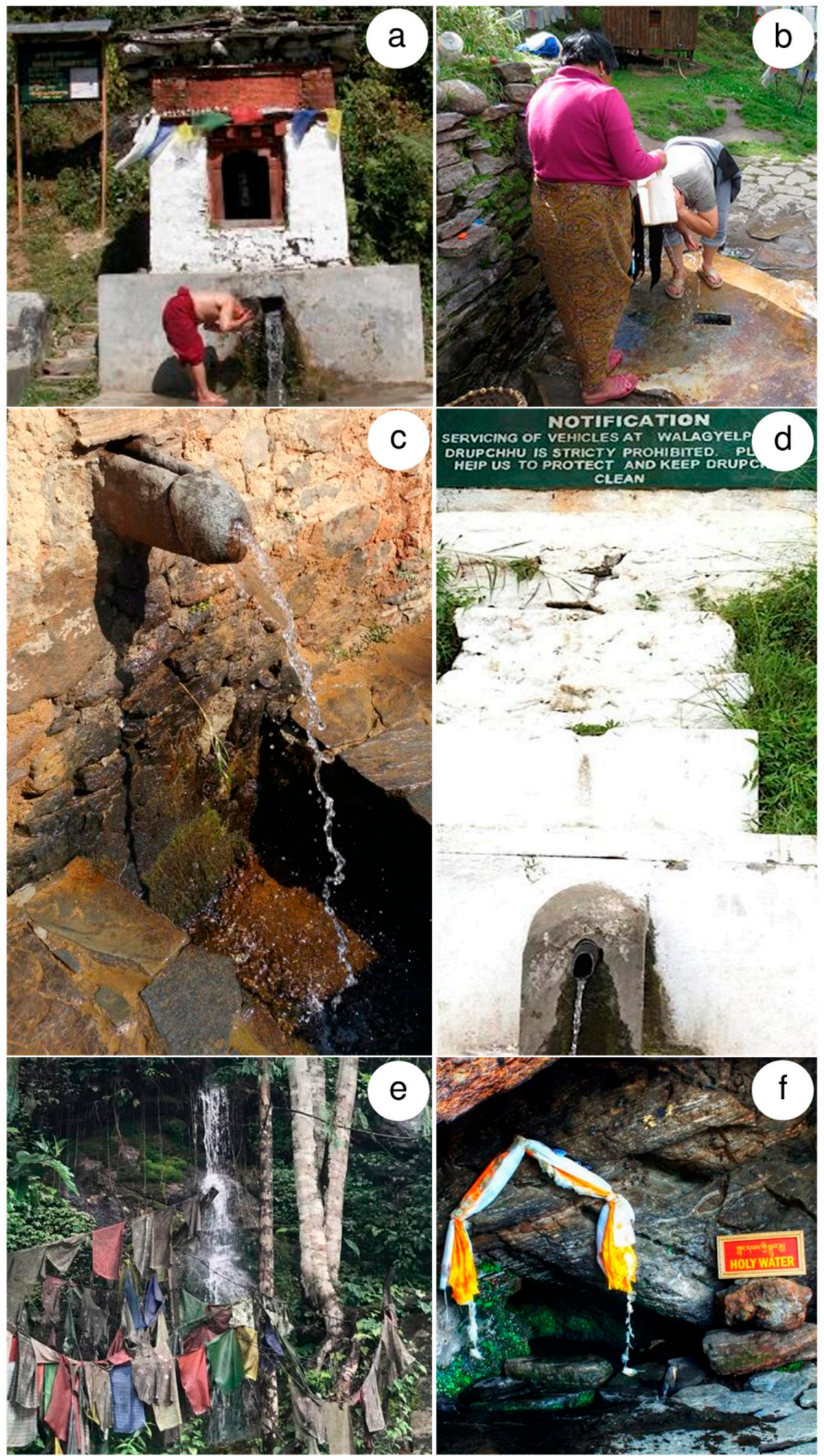

Figure 6. Selected natural holy spring waters of Bhutan: (a) Tsheringma holy water; (b) Kurje holy water; (c) Dechenphug holy water; (d) Woolha Gyalp holy water; (e) Pelzo Gyem holy water; (f) Taktshang holy water. (Courtesy: K. Yeshi). Hoisting prayer flags around the holy sites increases the sacredness of the spring waters. 


\subsubsection{Blessed Rainwater (khrus-'bab chu)}

The blessed rainwater in the Bhutanese context (khrus-to bath or purify or cleanse; 'bab-descent; chu—water) means cleansing one's body with the blessed waters [31]. We found that Bhutanese celebrate the blessed rainy day (popularly known as khrus'bab dus-chen) at the end of every monsoon season, mainly in Eastern Bhutan. According to Bhutanese astrologers ( $g$ zhung-rtsi slob-dpon), the Sun enters Virgo (one of 12 zodiac constellations) and transits this area on average between August 23 and September 22. It coincides with the eighth Bhutanese month, and for a week, during which sun directly shines on the star Rishi (sage or drang-srong in Bhutanese language), which is Canopus (second brightest star seen from the earth). Astrologers believe that star Rishi is a medicinal star formed out of crystal (chu-shel) and gemstone (ke-ta-ka), which has the power to purify water. When the sun directly strikes the crystal and gemstone of the star Rishi, the rays emitting from the star reach the water bodies on earth and subsequently known to purify by disinfecting any pathogen and toxicity present in them. Thus, BSM medical system recommends using the water to treat diseases and enhance health and vitality during this week. An astrologer predicts the specific time of the week, and people put containers filled with water outside for overnight on that predicted day to receive the light of the Rishi star. Bhutanese use this blessed water for either drinking or bathing. People also bath in open streams and ponds during this event.

\subsection{Spiritually Empowered Waters}

We identified three types of spiritually empowered waters. They are mantra- empowered water (sngags-chu), ablution water or sacred cleansing water (khrus-gsol-chu), and ambrosia from the vase (bdud-rtsi bum-chu). There was no literature describing the precise quantity and variety of ingredients added into each type of waters as it depends upon the recipe for the ritual's specific tantric tradition and purposes. In Bhutan, the spiritual master (bla-ma) recommends mantra-empowered water patients afflicted by an evil spirit (gdon). The mantra-empowered water is made from regular drinking water, blessed with spiritual mantra power through visualization and chanting of prayers and mantras. The sacred cleansing water may or may not contain herbs, but saints or Buddhist master spiritually empower it by reciting the relevant mantras. This spiritually empowered water is usually poured over the patient (beginning from the head part) to heal the ailments associated with contamination or defilements, impurities (ma-dag-pa), and negativities (gnas-ngan).

Traditional physicians in the interview said that ambrosia from the vase contains water, Cinnamomum camphora (ga-bur) and Crocus sativus (dri-bzang) and stored inside a container or vase (bum-pa). People also take this water (bdud-rtsi bum-chu) during religious ceremonies such as sgrub-chen (sgrub-chen-great accomplishment practice or rite of high attainment for seven days), tshe-gcu (annual rituals performed by the public to bring in timely rain, bumper harvest, peace, prosperity, and sound health for the families and communities) and other related ceremonies. All temples, monastery, and home shrine have sacred cleansing waters (khrus-chu and bdud-rtsi bum-chu), and they sprinkle sacred water (bdud-rtsi bum-chu) every time they make an offering to appease deities. Anyone, including foreign tourists visiting the temple or monastery, experience sacred water or ambrosia from the vase (khrus-chu or bdud-rtsi bum-chu).

\subsection{Meta-Analysis of the Literature on the Clinical Studies of Balneotherapies}

We initially identified 135 potentially relevant articles, and out of it, 113 articles were excluded, including review articles and those that are not clinical studies. Finally, 22 randomized clinical trials (RCTs) regarding balneotherapy in various medical fields between 2012-2019 were analyzed (Table 5). The majority of RCTs were on the use of balneotherapy in osteoarthritis (six out of $22 \mathrm{RCTs}-27.3 \%$ ), and improvement of mental and quality of life (six out of 22 RCTs-27.3\%), followed by three RCTs in rheumatological and other musculoskeletal diseases, two each in fibromyalgia and psoriasis, one each 
in mastalgia and terminal stage cancer. Three trials were specific to knee osteoarthritis. These 22 RCTs evaluated a total of 1648 patients. Out of 22 RCTs, eight were from Italy and Hungary (four each), three from Turkey, two from Japan, Germany, Lithuania, and one from China, Thailand, France, Iceland, and the Republic Korea each. Balneotherapy yielded better or significant clinical improvements in patients (21 out of $22 \mathrm{RCTs}$ ) than their control groups. Although each RCT uses slightly different indices, measurement of the reduction in pain severity using the visual analogue scale (VAS) was the most common outcome examined in 12 out of 22 RCTs.

Balneotherapy not only improved clinical outcomes, but some of the RCTs did result in the reduction of the use of pharmacological drugs such as non-steroidal anti-inflammatory drugs (NSAIDs). A meta-analysis of 29 RCTs on the therapeutic effect of balneotherapy by Falagas et al. [32] indicated statistically significant pain improvement in patients with rheumatological and other musculoskeletal diseases. In another study on Chinese herbal bath therapy, the herbal bath is recommended as a complementary therapy to improve the pruritic symptoms in uremia patients [33]. Although, in almost all RCTs, balneotherapy significantly improved clinical outcomes in patients with various diseases, yet available literature is still inadequate to draw a concrete conclusion, including their biological mechanism of action. 
Table 5. Various clinical studies and trials on the effectiveness of balneotherapy for different diseases (a meta-analysis of the available literature)

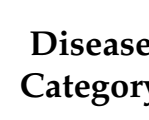

\section{Study Design and}

Treatment Arms

\section{Clinical Parameters}

Examined
Outcomes of the Study

\section{Study Population}

Geographical Area

(GA) and Thermal

Water Composition (TWC)
Group I $(n=30)$ : spa bath alone.

Group II $(n=30)$ :

continued with daily care routine.

Knee osteoarthritis

(Report 1)
Group I patients treated for 20 min in a bathtub for 12 applications for 2 weeks.

Assessment: baseline, $2 \mathrm{w}$ and after 3 months.

TM: both groups given pharmacological and non-pharmacological treatments.
Pain using visual analogue scale (VAS), Lequesne Index of Severity, Womac Index for knee OA total
Prospective randomized, single blind controlled trial.

60 patients. pain score (W-TPS), tota stiffness score (W-TSS), total physical function score (W-TPFS), Arthritis Impact Measurement Scale

(AIMS), Quality of Life

(QoL) using Medical

Outcomes Study 36-Item Short Form (SF-36).
At week 2: assessment of pain showed significant reduction in Group I (VAS, W-TPS, W-TSS, $\mathrm{W}$-TPFS, $p<0.001)$; Lequesne index score $(p<0.001)$; Group II showed no significant difference from baseline $(p=0.33$ in W-TPS $p=0.85$ in W-TSS, $p=0.75$ in

W-TPFS). SF-36 for Group I showed significant improvement $(p<0.001)$. Significance difference persisted during follow-up. After 3 months: significant reduction in the AIMS score in Group I $(p<0.001)$ and lasted during follow-up period. Group II showed no significance ( $p=0.87$ ).

Significant reduction in the NSAID and acetaminophen consumption in Group $(p<0.001)$. Non-significant in Group II.
GA: Siena, Italy TWC: $38^{\circ} \mathrm{C}$ rich in $\mathrm{Ca}^{++}, \mathrm{HCO}_{3}^{-}, \mathrm{SO}_{4}^{-}$
References

-


Table 5. Cont.

\begin{tabular}{|c|c|c|c|c|c|c|}
\hline $\begin{array}{l}\text { Disease } \\
\text { Category }\end{array}$ & $\begin{array}{l}\text { Study Design and } \\
\text { Treatment Arms }\end{array}$ & $\begin{array}{c}\text { Study Type \& } \\
\text { Study Population }\end{array}$ & $\begin{array}{c}\text { Clinical Parameters } \\
\text { Examined }\end{array}$ & Outcomes of the Study & $\begin{array}{l}\text { Geographical Area } \\
\text { (GA) and Thermal } \\
\text { Water Composition } \\
\text { (TWC) }\end{array}$ & References \\
\hline $\begin{array}{l}\text { General } \\
\text { physical and } \\
\text { mental effects. }\end{array}$ & $\begin{array}{c}\text { Group I }(n=19) \\
\text { Group II }(n=19) \\
\text { Both groups received } 2 \mathrm{w} \\
\text { intervention of immersion } \\
\text { bathing for } 10 \text { min } \\
\text { followed by } 2 \mathrm{w} \text { shower } \\
\text { bathing or vice versa. } \\
\text { Assessment: baseline, } 2 \mathrm{w} \\
\text { for each intervention. } \\
\text { TM: no additional. }\end{array}$ & $\begin{array}{c}\text { Randomized } \\
\text { intervention study. } \\
38 \text { healthy adults. }\end{array}$ & $\begin{array}{l}\text { Self-reported health status } \\
\text { measure using VAS, health } \\
\text { and mood state during } \\
\text { intervention period } \\
\text { measured using Japanese } \\
\text { versions of 8-Item Short } \\
\text { Form Health Survey (SF-8) } \\
\text { and a short form of the } \\
\text { Profile of Mood States } \\
\text { (POMS). }\end{array}$ & $\begin{array}{l}\text { VAS scores significantly higher for } \\
\text { self-reported health and skin }(p< \\
0.10) \text {, and for smile }(p<0.05) \\
\text { during bathing intervention. } \\
\text { Additionally, significantly lower } \\
\text { VAS score for fatigue, stress, and } \\
\text { pain }(p<0.05) \text { during bathing } \\
\text { intervention than showering } \\
\text { intervention. } \\
\text { SF-8 score significant in bathing } \\
\text { intervention ( } p<0.05) ; \text { POMS } \\
\text { score for tension-anxiety, } \\
\text { depression-dejection, and } \\
\text { anger-hostility significantly lower } \\
(p<0.05) \text { during bathing } \\
\text { intervention. }\end{array}$ & $\begin{array}{l}\text { GA: Karadakara, } \\
\text { Japan } \\
\text { TWC: } 40^{\circ} \mathrm{C} \text { warm } \\
\text { water bath }\end{array}$ & [35] \\
\hline $\begin{array}{l}\text { Terminal stage } \\
\text { cancer }\end{array}$ & $\begin{array}{c}\text { Group I }(n=24) \\
\text { One rejected; three did not } \\
\text { receive mechanical bathing. } \\
\text { Only } 20 \text { received } \\
\text { mechanical bathing for } 5 \\
\text { min using Marine Court } \\
\text { SB7000. } \\
\text { Assessment: } 5 \text { min } \\
\text { duration. } \\
\text { TM: patients took a cup of } \\
\text { water before and after } \\
\text { bathing to prevent } \\
\text { dehydration. }\end{array}$ & $\begin{array}{l}\text { Pilot study. } \\
24 \text { adults }(>20 \\
\text { years old) in } \\
\text { terminal cancer } \\
\text { stage. }\end{array}$ & $\begin{array}{l}\text { Patients' state of anxiety } \\
\text { assessed using the } \\
\text { State-Trait Anxiety } \\
\text { Inventory (STAI) }\end{array}$ & $\begin{array}{l}16 \text { patients out of } 23 \text { showed } \\
\text { significant reduction in the } \\
\text { anxiety as evaluated by STAI ( } p< \\
0.0001) \text { after mechanical bathing. } \\
\text { Most patients felt comfortable and } \\
\text { relaxed in their verbal responses } \\
\text { post-bathing. Thus, safe, and } \\
\text { pain-relieving for patients in the } \\
\text { terminal stage cancer. }\end{array}$ & $\begin{array}{l}\text { GA: Kyoto, Japan } \\
\text { TWC: } 41^{\circ} \mathrm{C} \text { water } \\
\text { bath. }\end{array}$ & [36] \\
\hline
\end{tabular}


Table 5. Cont.

\begin{tabular}{|c|c|c|c|c|c|c|}
\hline $\begin{array}{l}\text { Disease } \\
\text { Category }\end{array}$ & $\begin{array}{l}\text { Study Design and } \\
\text { Treatment Arms }\end{array}$ & $\begin{array}{c}\text { Study Type \& } \\
\text { Study Population }\end{array}$ & $\begin{array}{c}\text { Clinical Parameters } \\
\text { Examined }\end{array}$ & Outcomes of the Study & $\begin{array}{l}\text { Geographical Area } \\
\text { (GA) and Thermal } \\
\text { Water Composition } \\
\text { (TWC) }\end{array}$ & References \\
\hline Depression & $\begin{array}{c}\text { Group I }(n=17) \text { : } \\
\text { hyperthermic bath alone. } \\
\text { Group II }(n=19) \text { : sham } \\
\text { condition. } \\
\text { Group I received } 2 \\
\text { hyperthermic baths per } \\
\text { week for } 4 \text { w or a } \\
\text { sham/placebo group with } \\
\text { green light. } \\
\text { Assessment: baseline, } 2 \mathrm{w}, \\
4 \text { w (follow-up). } \\
\text { TM: no changes in } \\
\text { antidepressant treatment } \\
\text { allowed during the study } \\
\text { period. }\end{array}$ & $\begin{array}{l} \\
\text { Single-site, } \\
\text { parallel-group, } \\
\text { randomized } \\
\text { controlled trial of } \\
\text { hyperthermic bath } \\
\text { vs sham-placebo } \\
\text { (green } \\
\text { light) } \\
36 \text { patients. }\end{array}$ & $\begin{array}{l}\text { Outcome was measured } \\
\text { using the 17-item Hamilton } \\
\text { Scale for Depression } \\
\text { (HAM-D) Total Score from } \\
\text { baseline to } 2 \mathrm{w} \text { time point. }\end{array}$ & $\begin{array}{c}\text { At week 2: Group I showed } \\
\text { significant }(p=0.037) \text { difference in } \\
\text { the change in HAM-D } \text { D }_{\text {Total Score }} \\
3.14 \text { points after } 4 \text { interventions } \\
\text { suggesting the efficacy of } \\
\text { hyperthermic bath in depressed } \\
\text { patients. }\end{array}$ & $\begin{array}{c}\text { GA: Freiburg, } \\
\text { Germany } \\
\text { TWC: } 40^{\circ} \mathrm{C} \text { water } \\
\text { bath. }\end{array}$ & [37] \\
\hline $\begin{array}{l}\text { Stress response } \\
\text { and } \\
\text { psychological } \\
\text { state }\end{array}$ & $\begin{array}{c}\text { Group I }(n=78) \text { : moor bath } \\
\text { alone. } \\
78 \text { participants received a } \\
\text { total of seven moor } \\
\text { applications for } 20 \mathrm{~min} \\
\text { each followed by } 20 \mathrm{~min} \\
\text { resting period. } \\
\text { Assessment: baseline, } \\
1 \mathrm{w}, 3 \mathrm{w} \text {. } \\
\text { TM: no additional. }\end{array}$ & $\begin{array}{l}\text { Randomized } \\
\text { controlled pilot } \\
\text { study. } \\
78 \text { patients. }\end{array}$ & $\begin{array}{l}\text { Salivary cortisol level, } \\
\text { blood pressure and heart } \\
\text { rate were measured before } \\
\text { and after moor bath. Mood } \\
\text { state in participants was } \\
\text { measured using the } \\
\text { German version of the } \\
\text { multidimensional Mood } \\
\text { State Questionnaire } \\
\text { (MDBF). }\end{array}$ & $\begin{array}{c}61.5 \% \text { of patients showed } \\
\text { significant reduction in cortisol } \\
\text { level between pre- and post-moor } \\
\text { bath in week } 1(p<0.008) \text {; and in } \\
46.2 \% \text { of participants between pre- } \\
\text { and post-moor bath in week } 3 \text { was } \\
\text { non-significant ( } p<0.1617) \text {. } \\
\text { Blood pressure was after moor } \\
\text { bath. } \\
\text { Heart rate increased during moor } \\
\text { bath but was significantly lower } \\
\text { in week } 3 \text { compared to week } 1 . \\
\text { Mood state significant improved } \\
\text { after both moor baths. }\end{array}$ & $\begin{array}{c}\text { GA: Bavaria, Germany } \\
\text { TWC: } 42{ }^{\circ} \mathrm{C} \text { moor } \\
\text { bath. }\end{array}$ & [38] \\
\hline
\end{tabular}


Table 5. Cont.

\begin{tabular}{|c|c|c|c|}
\hline $\begin{array}{l}\text { Disease } \\
\text { Category }\end{array}$ & $\begin{array}{l}\text { Study Design and } \\
\text { Treatment Arms }\end{array}$ & $\begin{array}{c}\text { Study Type \& } \\
\text { Study Population }\end{array}$ & $\begin{array}{c}\text { Clinical Parameters } \\
\text { Examined }\end{array}$ \\
\hline
\end{tabular}

\section{Outcomes of the Study}

tudy

Sleep disorder (difficulty in falling asleep ( $p=0.017)$; dreaminess, nightmare suffering, and restless sleep ( $p=0.013)$; easy awakening $(p=0.003)$ and difficulty in falling into sleep again after awakening $(p=0.016)$; and mental stress $(p=$

$0.031)$ and problems of general
Randomized clinical trial.

Mental stress, sleep disorder, and general health problems.
Group I $(n=223)$ : hot spring balneotherapy alone. Group II $(n=139)$ : did not receive hot spring balneotherapy. Group I received head-out immersion hot spring balneotherapy of $30 \mathrm{~min}$ for at least 1-3 times a week for 5 months. Assessment: baseline, 3 months. TM: no additional.

\section{2 sub-healthy}

participants (age group: 18-65 years old)
Mental and physical state were examined using two sets of self-designed examination center. questionnaires in the health

health (head pain $(p=0.026)$, joint pain $(p=0.009)$, leg or foot cramps $(p=0.001)$, blurred vision $(p=$ $0.009)$ ) were relieved significantly

in Group I compared to control (Group II).

Relief of insomnia, fatigue, and leg or foot cramps was greater in old-age group than in young age-age group $(p<0.05)$ Waist circumference was significantly in women below age of 55 years $(p<0.05)$ but not in
Geographical Area

(GA) and Thermal

Water Composition

$$
\text { (TWC) }
$$

References

\author{
GA: Chongqing, \\ China. \\ TWC: $36-42{ }^{\circ} \mathrm{C}$ rich in \\ $\mathrm{SO}_{4}{ }^{2-}, \mathrm{Ca}^{2+}, \mathrm{Mg}^{2+}, \mathrm{Cl}$ \\ metaboric acid \\ fluorine, and $\mathrm{Sr}$.
} men. 
Table 5. Cont.

\begin{tabular}{|c|c|c|c|c|c|c|}
\hline $\begin{array}{l}\text { Disease } \\
\text { Category }\end{array}$ & $\begin{array}{l}\text { Study Design and } \\
\text { Treatment Arms }\end{array}$ & $\begin{array}{c}\text { Study Type \& } \\
\text { Study Population }\end{array}$ & $\begin{array}{c}\text { Clinical Parameters } \\
\text { Examined }\end{array}$ & Outcomes of the Study & $\begin{array}{c}\text { Geographical Area } \\
\text { (GA) and Thermal } \\
\text { Water Composition } \\
\text { (TWC) }\end{array}$ & References \\
\hline $\begin{array}{l}\text { Distress and } \\
\text { health risk. }\end{array}$ & $\begin{array}{c}\text { Group I }(n=65) \text { : } \\
\text { geothermal water group. } \\
\text { Group II ( } n=65) \text { : control } \\
\text { group. } \\
\text { Group I received } \\
\text { balneotherapy for } 5 \text { days a } \\
\text { week over a } 2 \text { weeks } \\
\text { period. Control group did } \\
\text { not receive therapy. } \\
\text { Assessment: baseline, } 2 \text { w. } \\
\text { No follow-ups. } \\
\text { TM: no additional. }\end{array}$ & $\begin{array}{c}\text { Open label } \\
\text { randomized } \\
\text { controlled trial. } \\
130 \text { male seafarers } \\
\text { aged between } 25 \\
\text { and } 64 \mathrm{y} .\end{array}$ & $\begin{array}{l}\text { Severity of distress } \\
\text { symptoms and health risk } \\
\text { change post-balneotherapy } \\
\text { was measured using } \\
\text { self-assessment scale } \\
\text { General Symptoms Distress } \\
\text { Scale (GSDS). }\end{array}$ & $\begin{array}{c}\text { After week } 2 \text {, Group I } \\
\text { experienced significant reduction } \\
\text { in the number of stressed } \\
\text { symptoms }(p<0.001) \text { or } 60 \% \text {, } \\
\text { intensity of stress symptoms by } \\
41 \% \text { and stress management } \\
\text { improved by } 32 \% \text {. } \\
\text { Probability of general health risk } \\
\text { decreased by } 18 \%(p=0.01) .\end{array}$ & $\begin{array}{c}\text { GA: Klaipeda, } \\
\text { Lithuania. } \\
\text { TWC: } 34.6^{\circ} \mathrm{C}_{\text {rich in }} \\
\mathrm{Na}^{+}, \mathrm{Cl}^{-}, \mathrm{SO}_{4}{ }^{2-}, \\
\mathrm{Ca}^{2+}, \mathrm{Mg}^{2+} .\end{array}$ & [40] \\
\hline $\begin{array}{l}\text { Stress and } \\
\text { fatigue }\end{array}$ & $\begin{array}{c}\text { Group I }(n=65) \text { : } \\
\text { Geothermal group. } \\
\text { Group II ( } n=50) \text { : music } \\
\text { group. } \\
\text { Group III ( } n=65) \text { : Control } \\
\text { group. } \\
\text { Group I received a } \\
\text { head-out immersion } \\
\text { balneotherapy sessions for } \\
15 \text { min daily, five times a } \\
\text { week, for } 2 \text { weeks. } \\
\text { Group II received music } \\
\text { therapy for } 20 \text { min } \\
\text { Assessment: baseline, w. } \\
\text { TM: no additional. }\end{array}$ & $\begin{array}{c}\text { Prospective open } \\
\text { label randomized } \\
\text { controlled parallel } \\
\text { group } \\
\text { biomedical trial. } \\
180 \text { male seamen } \\
\text { (25-64 years of age } \\
\text { group) with stress } \\
\text { and fatigue level } \\
\text { more than } 2 \text { (VAS } \\
\text { from } 0 \text { to } 10) .\end{array}$ & $\begin{array}{c}\text { Stress and fatigue } \\
\text { outcomes were assessed } \\
\text { using the self-administered } \\
\text { general symptoms distress } \\
\text { scale (GSDS), the } \\
\text { Multidimensional Fatigue } \\
\text { Inventory (MFI), and the } \\
\text { Cognitive Failures } \\
\text { Questionnaire (CFQ). }\end{array}$ & $\begin{array}{c}\text { After week 2, Group I } \\
\text { (geothermal group) showed a } \\
\text { significant therapeutic response } \\
\text { compared to music and control } \\
\text { groups including significant } \\
\text { positive changes in CFQ, mood, } \\
\text { and pain }(p<0.001) \text {. } \\
\text { Balneotherapy treatment showed } \\
\text { significant reduction in the blood } \\
\text { pressure }(p=0.004) \text {, respiratory } \\
\text { rate }(p=0.001), \text { while music } \\
\text { therapy showed significant } \\
\text { reduction in respiratory rate } \\
(p=0.009) \text { with significance } \\
\text { differences among groups } \\
(p<0.001) \text {. } \\
\text { Only geothermal group showed } \\
\text { significant less medication use } \\
(p=0.047) \text {. }\end{array}$ & $\begin{array}{c}\text { GA: Klaipeda, } \\
\text { Lithuania. } \\
\text { TWC: } 34.6^{\circ} \mathrm{C} \text { rich in } \\
\mathrm{Na}^{+}, \mathrm{Cl}^{-}, \mathrm{SO}_{4}{ }^{2-} \\
\mathrm{Ca}^{2+}, \mathrm{Mg}^{2+} .\end{array}$ & [41] \\
\hline
\end{tabular}


Table 5. Cont.

\begin{tabular}{|c|c|c|c|c|c|c|}
\hline $\begin{array}{l}\text { Disease } \\
\text { Category }\end{array}$ & $\begin{array}{l}\text { Study Design and } \\
\text { Treatment Arms }\end{array}$ & $\begin{array}{c}\text { Study Type \& } \\
\text { Study Population }\end{array}$ & $\begin{array}{c}\text { Clinical Parameters } \\
\text { Examined }\end{array}$ & Outcomes of the Study & $\begin{array}{c}\text { Geographical Area } \\
\text { (GA) and Thermal } \\
\text { Water Composition } \\
\text { (TWC) }\end{array}$ & References \\
\hline $\begin{array}{c}\text { Knee } \\
\text { osteoarthritis } \\
\text { (Report 2) }\end{array}$ & $\begin{array}{c}\text { Group I }(n=25): \\
\text { consecutive treatment } \\
\text { group. } \\
\text { Group II }(n=25) \text { : } \\
\text { intermittent treatment } \\
\text { group. } \\
\text { Group I received total of } 10 \\
\text { consecutive treatment } \\
\text { sessions for } 2 \text { weeks ( } 5 \\
\text { days / week), While Group } \\
\text { II received total of } 10 \\
\text { intermittent treatment } \\
\text { sessions for } 5 \text { weeks (two } \\
\text { times / week). Tap water } \\
\text { bath was given for } 20 \text { min } \\
\text { during treatment sessions } \\
\text { followed by } 30 \text { min rest } \\
\text { and then } 2 \text {-cm thick local } \\
\left.\text { peloid packs (45 }{ }^{\circ} \mathrm{C}\right) \text { was } \\
\text { applied on knee. } \\
\text { Assessment: baseline, } 2 \text { w, } \\
5 \text { w, } 12 \text { w post-treatment. } \\
\text { TM: no additional. }\end{array}$ & $\begin{array}{l}\text { Randomized } \\
\text { double-blind } \\
\text { clinical trial. } \\
50 \text { patients. }\end{array}$ & $\begin{array}{c}\text { Degree of pain was } \\
\text { assessed using VAS, } \\
\text { well-being of patients (pain, } \\
\text { stiffness, and physical } \\
\text { functions) using Western } \\
\text { Ontario and McMaster } \\
\text { Universities Osteoarthritis } \\
\text { Index (WOMAC), quality } \\
\text { of life (QoL) using SF-36. }\end{array}$ & $\begin{array}{c}\text { Both consecutive and intermittent } \\
\text { balneological treatment regimens } \\
\text { of } \\
\text { knee osteoarthritis showed } \\
\text { statistically significant clinical } \\
\text { effects as well as effects on the } \\
\text { QoL till } 3 \text { months (similar } \\
\text { efficacy). } \\
\text { After } 3 \text { months, joint stiffness } \\
\text { (WOMAC), } \\
\text { role-emotional (SF-36), and } \\
\text { vitality (SF-36) in group } 1 \text { and for } \\
\text { mental health (SF-36) in both } \\
\text { groups became non-significant. }\end{array}$ & $\begin{array}{c}\text { GA: France } \\
\text { TWC: mineral water } \\
\left(38^{\circ} \mathrm{C}\right) ; \text { peloid } \\
\text { (Pelomin) } 45^{\circ} \mathrm{C} \text {. }\end{array}$ & [42] \\
\hline
\end{tabular}


Table 5. Cont.

\begin{tabular}{|c|c|c|c|c|c|c|}
\hline $\begin{array}{l}\text { Disease } \\
\text { Category }\end{array}$ & $\begin{array}{c}\text { Study Design and Treatment } \\
\text { Arms }\end{array}$ & $\begin{array}{l}\text { Study Type \& } \\
\text { Study Population }\end{array}$ & $\begin{array}{l}\text { Clinical Parameters } \\
\text { Examined }\end{array}$ & Outcomes of the Study & $\begin{array}{c}\text { Geographical Area } \\
\text { (GA) and Thermal } \\
\text { Water Composition } \\
\text { (TWC) }\end{array}$ & References \\
\hline Mastalgia & $\begin{array}{c}\text { Group I }(n=20) \text { : } \\
\text { balneotherapy plus } \\
\text { conventional treatment of } \\
\text { mastalgia program. } \\
\text { Group II }(n=20) \text { : } \\
\text { Conventional treatment of } \\
\text { mastalgia program alone. } \\
\text { Both groups received } \\
\text { conventional treatment for six } \\
\text { weeks. } \\
\text { Group I received a total of } 10 \\
\text { sessions of balneotherapy } \\
\text { during last two weeks. } \\
\text { Assessment: baseline, } 6 \text { w. } \\
\text { TM: Conventional treatment } \\
\text { included reassurance } \\
\text { regarding the absence of breast } \\
\text { cancer, refraining from } \\
\text { methylxanthine containing } \\
\text { foods and beverages, use of a } \\
\text { sports brassiere and } \\
\text { paracetamol (maximum daily } \\
\text { dose of } 1000 \text { mg) were } \\
\text { recommended for both groups } \\
\text { for } 6 \text { weeks. No additional. }\end{array}$ & $\begin{array}{l}\text { Assessor-blinded } \\
\text { randomized } \\
\text { controlled clinical } \\
\text { study. } \\
40 \text { female } \\
\text { mastalgia patients. }\end{array}$ & $\begin{array}{l}\text { Mastalgia was assessed } \\
\text { using the Breast pain } \\
\text { questionnaire (BPQ), QoL } \\
\text { was assessed using the } \\
\text { Turkish version of the Short } \\
\text { Form-36 (SF-36). Serum } \\
\text { level of cytokines was } \\
\text { measured using ELISA kits. }\end{array}$ & $\begin{array}{l}\text { At week } 6 \text {, balneotherapy group } \\
\text { showed significant improvement } \\
\text { in total BPS ( } p=0.001) \text {, VAS ( } p= \\
0.039) \text {, present pain intensity (PPI) } \\
\qquad(p=0.004) \text {. } \\
\text { Significant decrease in the } \\
\text { cytokine TNF- } \mu \text { level ( } p=0.003) \\
\text { in balneotherapy group. }\end{array}$ & $\begin{array}{c}\text { GA: Haymana, Turkey. } \\
\text { TWC: } 44^{\circ} \mathrm{C} \text { rich in } \\
\mathrm{Ca}^{+}, \mathrm{Mg}^{2+}, \mathrm{HCO}_{3}{ }^{-}, \\
\mathrm{F}^{-}, \text {chrome, } \mathrm{Cu}^{2+}, \\
\mathrm{Zn}^{2+} .\end{array}$ & [43] \\
\hline
\end{tabular}


Table 5. Cont.

\begin{tabular}{|c|c|c|c|c|c|c|}
\hline $\begin{array}{l}\text { Disease } \\
\text { Category }\end{array}$ & $\begin{array}{l}\text { Study Design and } \\
\text { Treatment Arms }\end{array}$ & $\begin{array}{c}\text { Study Type \& } \\
\text { Study Population }\end{array}$ & $\begin{array}{c}\text { Clinical Parameters } \\
\text { Examined }\end{array}$ & Outcomes of the Study & $\begin{array}{l}\text { Geographical Area } \\
\text { (GA) and Thermal } \\
\text { Water Composition } \\
\text { (TWC) }\end{array}$ & References \\
\hline $\begin{array}{l}\text { Chronic pelvic } \\
\text { pain. }\end{array}$ & $\begin{array}{l}16 \text { patients received } 10 \\
\text { heated seawater baths for } \\
20 \text { min followed by } \\
\text { application of } 10 \text { mud-pack } \\
\text { applications for } 10 \text { min on } \\
\text { pelvic area in the morning } \\
\text { and afternoon at fixed time } \\
\text { for five days. } \\
\text { Assessment: baseline, } 5 \mathrm{~d}, 1 \\
\text { month (Follow-up). } \\
\text { TM: patients were allowed } \\
\text { to continue with previously } \\
\text { prescribed pain } \\
\text { medication. }\end{array}$ & $\begin{array}{l}\text { Open, prospective } \\
\text { pilot study. } \\
16 \text { patients with } \\
\text { Chronic pelvic } \\
\text { pain (20-75 years } \\
\text { age group) }\end{array}$ & $\begin{array}{l}\text { VAS for pain, the } \\
\text { Cleveland Clinic } \\
\text { Constipation Score (CCCS), } \\
\text { the Overactive Bladder } \\
\text { Symptom Score (OABSS), } \\
\text { the Female Sexual Function } \\
\text { Index (FSFI), and SF-36 } \\
\text { were measured thrice: } \\
\text { before, immediately after } \\
\text { treatment and at the end of } \\
\text { one-month post-treatment. }\end{array}$ & $\begin{array}{l}\text { Significant improvement in } \\
\text { almost all score after } \\
\text { balneotherapy-VAS }(p=0.003) \text {, } \\
\text { CCCS }(p=0.203) \text {, OABSS }(p= \\
\text { 0.049), FSFI }(p=0.441), \text { SF-36 } \\
\text { (pain, } p=0.008) \text {; social } \\
\text { functioning, } p=0.008 \text {; role } \\
\text { limitations due to emotional } \\
\text { problem, } p=0.002 \text {; emotional } \\
\text { wellbeing, } p=0.012 ; \text { physical } \\
\text { functioning, } p=0.013)\end{array}$ & $\begin{array}{l}\text { GA: Wando Island, } \\
\text { Republic of Korea. } \\
\text { TWC: sea water pool } \\
\left(38^{\circ} \mathrm{C}\right) \text { and mud pack } \\
\left(40^{\circ} \mathrm{C}\right) \text { rich in } \mathrm{Ca}^{2+} \\
\mathrm{Mg}^{2+}, \mathrm{K}^{+} \text {, and } \mathrm{Na}^{+} \text {. }\end{array}$ & [44] \\
\hline
\end{tabular}


Table 5. Cont.

\begin{tabular}{|c|c|c|c|c|c|c|}
\hline $\begin{array}{l}\text { Disease } \\
\text { Category }\end{array}$ & $\begin{array}{l}\text { Study Design and } \\
\text { Treatment Arms }\end{array}$ & $\begin{array}{c}\text { Study Type \& } \\
\text { Study Population }\end{array}$ & $\begin{array}{c}\text { Clinical Parameters } \\
\text { Examined }\end{array}$ & Outcomes of the Study & $\begin{array}{l}\text { Geographical Area } \\
\text { (GA) and Thermal } \\
\text { Water Composition } \\
\text { (TWC) }\end{array}$ & References \\
\hline Fibromyalgia. & $\begin{array}{c}\text { Group I }(n=50) \text { : } \\
\text { balneotherapy alone. } \\
\text { Group II ( } n=50) \text { : tape } \\
\text { water alone. } \\
\text { Group I received } \\
\text { balneotherapy with } \\
\text { Vetriolo's water and Group } \\
\text { II (control group) received } \\
\text { heated tape water for } 15 \\
\text { min daily immersion (6 } \\
\text { times/week) for two } \\
\text { consecutive weeks. } \\
\text { Assessment: baseline, } 2 \text { w, } \\
3 \text { months, } 6 \text { months. } \\
\text { TM: both groups given } \\
\text { pharmacological and } \\
\text { non-pharmacological } \\
\text { treatments. }\end{array}$ & $\begin{array}{c}\text { Prospective } \\
\text { randomized, } \\
\text { controlled, parallel } \\
\text { group, } \\
\text { double-blind trial. } \\
100 \text { patients. }\end{array}$ & $\begin{array}{l}\text { The primary outcome } \\
\text { measurements-change of } \\
\text { global pain using VAS, and } \\
\text { Fibromyalgia Impact } \\
\text { Questionnaire total score } \\
\text { (FIQ-Total) from baseline to } \\
15 \text { days. Secondary } \\
\text { outcome } \\
\text { measurement-using } \\
\text { Widespread Pain Index } \\
\text { (WPI), Symptom Severity } \\
\text { Scale Score (SS score), Short } \\
\text { Form Health Survey } \\
\text { (SF-12), State-Trait Anxiety } \\
\text { Inventory (STAI), and } \\
\text { Center for Epidemiologic } \\
\text { Studies Depression Scale } \\
\text { (CES-D). }\end{array}$ & $\begin{array}{c}\text { At week } 2, \text { VAS in the } \\
\text { balneotherapy (BT) group, was } \\
\text { significant }(p<0.0001) \text { reduced } \\
\text { and persisted at 3-and 6-month } \\
\text { follow-up. VAS was } \\
\text { non-significant in control group. } \\
\text { FIQ total score in the BT group } \\
\text { improved significantly after } 2 \\
\text { weeks ( } p<0.001 \text { ) and } \\
\text { persisted significantly until } 6 \\
\text { months ( } p<0.0001 \text { ). } \\
\text { significant reduction in WPI in BT } \\
\text { group after week } 2 \text { and persisted } \\
\text { until } 6 \text { months- } p<0.0001 \text {. in } \\
\text { control group- } p<0.05 \text {. } \\
\text { SS score in BT group- } p< \\
0.05-0.0001 \text { until } 6 \text { months. } \\
\text { Significant improvement of SF-12 } \\
\text { MCS and CES-D in BT group-p }<< \\
0.01 \text { and persisted until } 6 \text { months } \\
\text { follow-up ( } p<0.0001 \text { and } p<0.05 \\
\text { respectively). }\end{array}$ & $\begin{array}{l}\text { GA: Trento, Italy. } \\
\text { TWC: } 36^{\circ} \mathrm{C} \text { rich in } \\
\mathrm{SO}_{4}{ }^{2-}, \mathrm{Ca}_{2}{ }^{+}, \mathrm{Mg}^{2+} \\
\text { and } \mathrm{Fe}^{2+}\end{array}$ & [45] \\
\hline
\end{tabular}


Table 5. Cont.

\begin{tabular}{|c|c|c|c|c|c|c|}
\hline $\begin{array}{l}\text { Disease } \\
\text { Category }\end{array}$ & $\begin{array}{l}\text { Study Design and } \\
\text { Treatment Arms }\end{array}$ & $\begin{array}{c}\text { Study Type \& } \\
\text { Study Population }\end{array}$ & $\begin{array}{c}\text { Clinical Parameters } \\
\text { Examined }\end{array}$ & Outcomes of the Study & $\begin{array}{c}\text { Geographical Area } \\
\text { (GA) and Thermal } \\
\text { Water Composition } \\
\text { (TWC) }\end{array}$ & References \\
\hline Osteoarthritis & $\begin{array}{c}\text { Group I }(n=26) \text { : jet } \\
\text { massage treatment in } \\
\text { thermal water. } \\
\text { Group II }(n=24) \text { : jet } \\
\text { massage treatment in tap } \\
\text { water. } \\
\text { Treatment include } 30 \text { min } \\
\text { session for } 5 \text { days in a week } \\
\text { for } 3 \text { weeks (total } 15 \\
\text { treatments). } \\
\text { Assessment: baseline, } 3 \mathrm{w} \text {, } \\
3 \text { months. } \\
\text { TM: no additional. }\end{array}$ & $\begin{array}{l}\text { Randomized } \\
\text { double-blind } \\
\text { controlled study. } \\
50 \text { osteoarthritis } \\
\text { patients (50-75 } \\
\text { years age group) }\end{array}$ & $\begin{array}{l}\text { Severity of pain using VAS, } \\
\text { well-being of patients (pain, } \\
\text { stiffness, and physical } \\
\text { functions) using Western } \\
\text { Ontario and McMaster } \\
\text { Universities Osteoarthritis } \\
\text { Index (WOMAC), quality } \\
\text { of life (QoL) using SF-36 } \\
\text { were determined before } \\
\text { first treatment, after last } \\
\text { treatment and } 3 \text { months } \\
\text { after the last treatment. }\end{array}$ & $\begin{array}{l}\text { Group I (treatment group) } \\
\text { showed significant improvement } \\
\text { in all scores compared to control } \\
\text { group II: VAS in Group at } 3 \mathrm{w} \text { and } \\
3 \text { months both significant }-p< \\
0.001 \text { and } p<0.008 \text { respectively. } \\
\text { Group II showed reduced pain } \\
\text { only at } 3 \text { w-p }-0.006 \text {. } \\
\text { WOMAC score in Group I was } \\
\text { significant at both } 3 \mathrm{~W} \text { and } 3 \\
\text { months: activity-p }<0.001 \text {, } \\
\text { stiffness- } p=0.004, \text { pain-p }- \\
0.002 \text { (at } 3 \text { w); activity- } p<0.001 \\
\text { (at } 3 \text { months). } \\
\text { SF-36-significant improvement } \\
\text { in vigorous activities in Group I } \\
(p=0.005) .\end{array}$ & $\begin{array}{c}\text { GA: Szigetvar, } \\
\text { Hungary. } \\
\text { TWC: } 34^{\circ} \mathrm{C} \text { rich in } \\
\mathrm{SO}_{4}{ }^{2-}, \mathrm{Na}^{+}, \mathrm{Cl}^{-}, \\
\mathrm{HCO}_{3}{ }^{-} \text {, and } \mathrm{H}_{2} \mathrm{SiO}_{3} .\end{array}$ & [46] \\
\hline
\end{tabular}


Table 5. Cont.

\begin{tabular}{|c|c|c|c|c|c|c|}
\hline $\begin{array}{l}\text { Disease } \\
\text { Category }\end{array}$ & $\begin{array}{l}\text { Study Design and } \\
\text { Treatment Arms }\end{array}$ & $\begin{array}{c}\text { Study Type \& } \\
\text { Study Population }\end{array}$ & $\begin{array}{c}\text { Clinical Parameters } \\
\text { Examined }\end{array}$ & Outcomes of the Study & $\begin{array}{l}\text { Geographical Area } \\
\text { (GA) and Thermal } \\
\text { Water Composition } \\
\text { (TWC) }\end{array}$ & References \\
\hline $\begin{array}{l}\text { Rheumatoid } \\
\text { arthritis }\end{array}$ & $\begin{array}{c}\text { Group I }(n=25) \text { : } \\
\text { balneotherapy plus } \\
\text { standard drug treatment. } \\
\text { Group II ( } n=25) \text { : standard } \\
\text { drug treatment alone. } \\
\text { Group I received } 12 \\
\text { balneotherapy sessions of } \\
20 \text { min (6 days/week } \\
\text { excluding Sunday) for } 2 \\
\text { weeks. } \\
\text { Assessment: baseline, } 2 \text { w. } \\
\text { TM: Both groups continued } \\
\text { their previous stable drug } \\
\text { regimen (conventional } \\
\text { DMARD including } \\
\text { methotrexate, } \\
\text { hydroxychloroquine, } \\
\text { leflunomide, or } \\
\text { sulfasalazine; } \\
\text { glucocorticoids). Patients } \\
\text { were } \\
\text { allowed to continue their } \\
\text { NSAIDs whenever needed. }\end{array}$ & $\begin{array}{l}\text { Single-blind } \\
\text { randomized } \\
\text { controlled trial. } \\
50 \text { patients }(>18 \\
\text { years of age) }\end{array}$ & $\begin{array}{c}\text { Severity of pain using VAS, } \\
\text { functional disability status } \\
\text { using Health Assessment } \\
\text { Questionnaire disability } \\
\text { index (HAQ-DI), } \\
\text { rheumatoid disease activity } \\
\text { using Disease Activity } \\
\text { Score for 28-joints of } 4 \\
\text { variables erythrocyte } \\
\text { sedimentation rate } \\
\text { (DAS28-4[ESR]), Oxidative } \\
\text { status using parameters viz. } \\
\text { MDA, NSSA, AOP, and } \\
\text { SOD were determined at } \\
\text { baseline and after the } \\
\text { treatment (2 w). }\end{array}$ & $\begin{array}{c}\text { Group I (treatment group) } \\
\text { showed significant improvement } \\
\text { in all parameters: VAS pain } \\
\text { score-reduced significantly } \\
(p=0.004) ; \text { HAQ-DI function } \\
\text { score-improved significantly } \\
(p=0.037) ; \text { DAS28-4[ESR] disease } \\
\text { activity ( } p=0.044) ; \text { swollen joint } \\
\text { count }(p=0.009) \text {. } \\
\text { Antioxidant effects-NSSA level } \\
\text { increased significantly ( } p=0.003) \\
\text { but not in control group. }\end{array}$ & $\begin{array}{c}\text { GA: Istanbul, Turkey. } \\
\text { TWC: } 36-37^{\circ} \mathrm{C} \text { rich in } \\
\mathrm{SO}_{4}^{2-}, \mathrm{Na}^{+}, \mathrm{Cl}^{-} \\
\mathrm{HCO}_{3}{ }^{-}, \mathrm{K}^{+}, \mathrm{Ca}^{2+} \\
\mathrm{Mg}^{2+} \text {, and } \mathrm{H}_{2} \mathrm{SiO}_{3} \\
\text { (major constituents). }\end{array}$ & [47] \\
\hline
\end{tabular}


Table 5. Cont.

\begin{tabular}{|c|c|c|c|c|c|c|}
\hline $\begin{array}{l}\text { Disease } \\
\text { Category }\end{array}$ & $\begin{array}{l}\text { Study Design and } \\
\text { Treatment Arms }\end{array}$ & $\begin{array}{c}\text { Study Type \& } \\
\text { Study Population }\end{array}$ & $\begin{array}{c}\text { Clinical Parameters } \\
\text { Examined }\end{array}$ & Outcomes of the Study & $\begin{array}{l}\text { Geographical Area } \\
\text { (GA) and Thermal } \\
\text { Water Composition } \\
\text { (TWC) }\end{array}$ & References \\
\hline $\begin{array}{l}\text { Chronic low } \\
\text { back pain. }\end{array}$ & $\begin{array}{l}\text { Group I }(n=52) \text { : thermal } \\
\text { mineral water treatment } \\
\text { plus usual musculoskeletal } \\
\text { pain killer treatment. } \\
\text { Group II ( } n=53) \text { : } \\
\text { traditional musculoskeletal } \\
\text { pain killer treatment alone. } \\
\text { Group I received } 15 \\
\text { sessions of balneotherapy } \\
\text { treatment for } 20 \\
\text { min/session for } 3 \text { weeks. } \\
\text { Assessment: baseline, } 3 \mathrm{w}, \\
9 \mathrm{w} \text { (follow-up). } \\
\text { TM: usual musculoskeletal } \\
\text { painkiller treatment. }\end{array}$ & $\begin{array}{c}\text { Randomized, } \\
\text { controlled } \\
\text { follow-up study. } \\
105 \text { patients (18-75 } \\
\text { years age group). }\end{array}$ & $\begin{array}{l}\text { Severity of pain using VAS } \\
\text { score, functional disability } \\
\text { using the Oswestry } \\
\text { Disability Index (ODI), and } \\
\text { the quality of life using the } \\
\text { EuroQol Five Dimensions } \\
\text { Questionnaire (EQ-5D) } \\
\text { were determined before, } \\
\text { right after, and } 9 \text { weeks } \\
\text { after } 3 \text { weeks therapy. }\end{array}$ & $\begin{array}{l}\text { VAS score of existing low back } \\
\text { pain at rest decreased significantly } \\
\text { in Group I ( } p<0.001 \text { ) after } 3 \text { weeks } \\
\text { balneotherapy and persisted in } \\
\text { the follow-up period. } \\
\text { ODI improved significantly in } \\
\text { Group I ( } p<0.001) \text {; EuroQol-5D } \\
\text { index on QoL improved } \\
\text { significantly ( } p<0.001) ; \\
\text { EuroQoL-VAS showed } \\
\text { improvement in the current state } \\
\text { of health }(p<0.001) \text {. } \\
\text { Number of patients requiring } \\
\text { NSAIDs, opioids, muscle } \\
\text { relaxants, and paracetamol for } \\
\text { low back pain decreased after } \\
\text { balneotherapy treatment. }\end{array}$ & $\begin{array}{c}\text { GA: Budapest, } \\
\text { Hungary. } \\
\text { TWC: } 38^{\circ} \mathrm{C} \text { rich in } \\
\mathrm{Ca}^{2+}, \mathrm{Mg}^{2+} \text {, and } \\
\mathrm{HCO}_{3}{ }^{-} \text {. }\end{array}$ & [48] \\
\hline $\begin{array}{l}\text { Obesity with } \\
\text { knee } \\
\text { osteoarthritis }\end{array}$ & $\begin{array}{l}\text { Group I }(n=10) \text { : received } \\
\text { hydrokinesitherapy with } \\
\text { salsobromoiodic water. } \\
\text { Group II }(n=10) \text { : did not } \\
\text { receive intervention. } \\
\text { Group I received treatment } \\
\text { of two sessions per week } \\
\text { for } 8 \text { consecutive weeks. } \\
\text { Assessment: baseline, } 8 \mathrm{w}, \\
6 \text { months (follow-up). } \\
\text { TM: no additional. }\end{array}$ & $\begin{array}{l}\text { Follow-up study. } \\
20 \text { patients. }\end{array}$ & $\begin{array}{l}\text { Severity of pain using VAS } \\
\text { score, clinical knee } \\
\text { evaluation using range of } \\
\text { motion (ROM) and lower } \\
\text { limb muscle strength, } \\
\text { Italian validated versions } \\
\text { of WOMAC and Lequesne } \\
\text { Algofunctional Index were } \\
\text { determined at baseline, } \\
\text { after } 8 \text { weeks and } 6 \text { months } \\
\text { after } 8 \text { weeks treatment. }\end{array}$ & $\begin{array}{c}\text { At week 8: VAS score for pain } \\
\text { reduced significantly in Group I } \\
(p=0.0039) \text { during walking in flat } \\
\text { surface. } \\
\text { At month 6: VAS core persisted } \\
\text { significantly low ( } p=0.00954) \text {. } \\
\text { WOMAC score reduced } \\
\text { significantly between baseline } \\
\text { and week } 8 \text { ( } p=0.0137) \text {, between } \\
\text { baseline and } 6 \text { months } \\
(p=0.006438) \text {. No significant } \\
\text { improvement in kinetic path } \\
\text { assessment. }\end{array}$ & $\begin{array}{l}\text { GA: Padua, Italy. } \\
\text { TWC: } 38^{\circ} \mathrm{C} \text { rich in } \\
\mathrm{Na}^{+}, \mathrm{SO}_{4}{ }^{2-}, \mathrm{Ca}^{2+}, \\
\mathrm{Mg}^{2+}, \mathrm{Cl}^{-}, \mathrm{K}^{+}, \mathrm{Br}^{-} \\
\text {and } \mathrm{HCO}_{3}-\end{array}$ & [49] \\
\hline
\end{tabular}


Table 5. Cont.

\begin{tabular}{|c|c|c|c|c|c|c|}
\hline $\begin{array}{l}\text { Disease } \\
\text { Category }\end{array}$ & $\begin{array}{l}\text { Study Design and } \\
\text { Treatment Arms }\end{array}$ & $\begin{array}{c}\text { Study Type \& } \\
\text { Study Population }\end{array}$ & $\begin{array}{c}\text { Clinical Parameters } \\
\text { Examined }\end{array}$ & Outcomes of the Study & $\begin{array}{c}\text { Geographical Area } \\
\text { (GA) and Thermal } \\
\text { Water Composition } \\
\text { (TWC) }\end{array}$ & References \\
\hline $\begin{array}{c}\text { Knee } \\
\text { osteoarthritis } \\
\text { (Report 3) }\end{array}$ & $\begin{array}{c}\text { Group I ( } n=27) \text { : physical } \\
\text { therapy alone. } \\
\text { Group II ( } n=19) \text { : } \\
\text { balneotherapy plus } \\
\text { physical therapy. } \\
\text { Both groups received } \\
\text { physical therapy including } \\
\text { hot pack ( } 20 \text { min/day), } \\
\text { transcutaneous electrical } \\
\text { nerve stimulation ( } 20 \\
\text { min/day), and } \\
\text { ultrasonography ( } 5 \\
\text { min/day) for } 5 \text { days/week } \\
\text { for total duration of } 3 \\
\text { weeks. } \\
\text { Group II received } \\
\text { concomitant balneotherapy } \\
\text { session lasting } 20 \text { min daily } \\
\text { at the same timing (5 } \\
\text { days/week) for } 3 \text { weeks. } \\
\text { Assessment: baseline, } 3 \text { w. } \\
\text { TM: NSAIDs not allowed } \\
\text { during treatment period. }\end{array}$ & $\begin{array}{l}\text { Controlled study. } \\
46 \text { patients ( } 57-85 \\
\text { years age group) }\end{array}$ & $\begin{array}{l}\text { Pain severity using VAS, } \\
\text { pain, stiffness, and physical } \\
\text { function using Western } \\
\text { Ontario and McMaster } \\
\text { Universities Arthritis Index } \\
\text { (WOMAC) determined } \\
\text { before and after treatment. }\end{array}$ & $\begin{array}{l}\text { Group II showed significant } \\
\text { improvement in all parameters } \\
\text { (all } p \text { values }<0.05) \text { compared to } \\
\text { control group which received only } \\
\text { physical therapy. }\end{array}$ & $\begin{array}{c}\text { GA: Ankara, Turkey. } \\
\text { TWC: } 38^{\circ} \mathrm{C} \text { rich in } \\
\mathrm{NaHCO}_{3}, \mathrm{~F}^{-} \text {, and } \\
\mathrm{Cl}^{-} .\end{array}$ & [50] \\
\hline
\end{tabular}


Table 5. Cont.

\begin{tabular}{|c|c|c|c|c|c|c|}
\hline $\begin{array}{l}\text { Disease } \\
\text { Category }\end{array}$ & $\begin{array}{l}\text { Study Design and } \\
\text { Treatment Arms }\end{array}$ & $\begin{array}{c}\text { Study Type \& } \\
\text { Study Population }\end{array}$ & $\begin{array}{c}\text { Clinical Parameters } \\
\text { Examined }\end{array}$ & Outcomes of the Study & $\begin{array}{c}\text { Geographical Area } \\
\text { (GA) and Thermal } \\
\text { Water Composition } \\
\text { (TWC) }\end{array}$ & References \\
\hline Fibromyalgia. & $\begin{array}{c}\text { Group I }(n=20) \text { : } \\
\text { balneotherapy alone. } \\
\text { Group II }(n=21) \text { : } \\
\text { mud-bath treatment alone. } \\
\text { Both groups received their } \\
\text { respective treatment once } \\
\text { daily for } 6 \text { days / week for } 2 \\
\text { weeks. Mud was applied at } \\
\text { a temperature of } 47^{\circ} \mathrm{C} \text { for } \\
10 \text { min, and thermal } \\
\text { immersion }\left(38^{\circ} \mathrm{C}\right) \text { for } 10 \\
\text { min daily. } \\
\text { Assessment: baseline, } 2 \mathrm{w}, \\
12 \mathrm{w} \text { follow-up. } \\
\text { TM: patients allowed to } \\
\text { continue their usual } \\
\text { pharmacological treatment. }\end{array}$ & $\begin{array}{l}\text { Multidisciplinary } \\
\text { approach study. } \\
41 \text { patients (31-69 } \\
\text { years age group). }\end{array}$ & $\begin{array}{l}\text { Pain severity using VAS, } \\
\text { Fibromyalgia Impact } \\
\text { Questionnaire (FIQ), and } \\
\text { SF-36 questionnaire for } \\
\text { evaluation of QoL were } \\
\text { measured at baseline, after } \\
\text { treatment (week 2), and } \\
\text { week } 12 \text { post-treatment. }\end{array}$ & $\begin{array}{c}\text { Group II showed better outcome: } \\
\text { Pain (VAS) }-p<0.05 ; \\
\text { FIQ_ } p<0.05 ; \mathrm{SF}-36 \text { PR physical } \\
\text { role }-p<0.05 \text {. } \\
\text { Group I showed significant } \\
\text { improvement in only pain } \\
\text { VAS }-p<0.05 \text {. Rest were } \\
\text { non-significant compared to } \\
\text { group that received mud-bath } \\
\text { alone. }\end{array}$ & $\begin{array}{c}\text { GA: Montecatini, Italy. } \\
\text { TWC: } 38^{\circ} \mathrm{C} \text { rich in } \\
\mathrm{Na}^{+}, \mathrm{SO}_{4}^{2-} \text {, and } \\
\mathrm{Mg}^{2+} .\end{array}$ & [51] \\
\hline
\end{tabular}


Table 5. Cont.

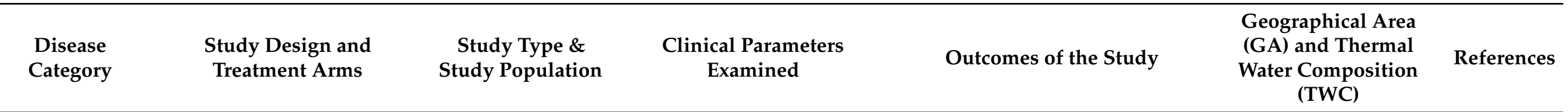

Group I $(n=26)$ : mineral water group.

Group II $(n=24)$ : organic fraction group.

Group III $(n=24)$ : tap water group.

Osteoarthritis Patients received a $30 \mathrm{~min}$ of the hips and thermal water treatment in

the knees.

a bathtub, five times a

week for 3 weeks.

Assessment: baseline, $3 \mathrm{w}$

3 months (Follow-up)

TM: suspended analgesic

medications during the

3-weeklong treatment.

\section{Double-blind}

randomized,

controlled clinical

trial.

74 patients (mean

age $67.3 \pm 4.48$

years)

\section{Range of movement (ROM)}

of the involved joints

Western Ontario, and

McMaster University

Osteoarthritis Index

(WOMAC), visual analog scale (VAS) for pain

severity and Short Form 36

questionnaire (SF-36) were

measure at baseline, after

first treatment and at 3

months post-treatment as a follow-up.
Group II (organic fraction)

showed significant improvement

in all parameters compared to

control group: ROM scores after 3

months (hip flexion $p=0.028$, hip abduction $p=0.004$, hip

adduction $p=0.002$, knee flexion and extension $p<0.001)$.

WOMAC total score $(p<0.001)$.

VAS pain reduction significant

both at $3 \mathrm{~W}(p<0.001)$ and 3months $(p=0.025)$.

$$
\text { SF-36 physical }
$$

functioning — significant

difference compared to tap water group $(p=0.02)$. Not significant different from mineral group in all parameters.
Group I $(n=80)$.

All patients received 3 week-long inward

balneotherapy-based rehabilitation.

Psoriasis

(Report 1)
Assessment: baseline, $3 \mathrm{w}$.

TM: Total of 13 out of 80 patients received

methotrexate, and another

5 patients received

biological therapy.
Multidisciplinary approach study.

80 patients (mean age $63.7 \pm 9.1)$
Severity and extent of psoriasis were measured by

the Psoriasis Area and

Severity Index (PASI)

highly sensitive $\mathrm{C}$-reactive

protein (CRP) was

measured from venous

blood samples before

treatment and discharge.
Both PASI score and CRP levels

showed improvement of psoriasis

after balneotherapy-based

rehabilitation. Methotrexate

receiving patients had

significantly lower PASI scores

both on admission $(p=0.015)$ and

before discharge
GA: Szigetvar,

Hungary.

TWC: $34^{\circ} \mathrm{C}$, mineral

composition not

defined.
GA: Hungary.

TWC: sulfuric water. 
Table 5. Cont.

\begin{tabular}{|c|c|c|c|c|c|c|}
\hline $\begin{array}{l}\text { Disease } \\
\text { Category }\end{array}$ & $\begin{array}{l}\text { Study Design and } \\
\text { Treatment Arms }\end{array}$ & $\begin{array}{c}\text { Study Type \& } \\
\text { Study Population }\end{array}$ & $\begin{array}{c}\text { Clinical Parameters } \\
\text { Examined }\end{array}$ & Outcomes of the Study & $\begin{array}{l}\text { Geographical Area } \\
\text { (GA) and Thermal } \\
\text { Water Composition } \\
\text { (TWC) }\end{array}$ & References \\
\hline $\begin{array}{l}\text { Psoriasis } \\
\text { (Report 2) }\end{array}$ & $\begin{array}{c}\text { Group I }(n=22) \text { : bathing in } \\
\text { geothermal seawater plus } \\
\text { UVB therapy (GSW+UVB). } \\
\text { Group II ( } n=22) \text { : Intensive } \\
\text { treatment with geothermal } \\
\text { seawater (IT-GSW). } \\
\text { Group III ( } n=24) \text { : UVB } \\
\text { therapy alone (UVB). } \\
\text { Group I received } \\
\text { GSW+UVB three } \\
\text { times / week for } 6 \text { weeks. } \\
\text { Group II received IT-GSW } \\
\text { for two weeks followed by } \\
\text { NB-UVB therapy for } 4 \\
\text { weeks. } \\
\text { Group III received UVB } \\
\text { three times/week for } 6 \\
\text { weeks. } \\
\text { Assessment: baseline, } 6 \text { w, } \\
10 \text { w. } \\
\text { TM: no additional. }\end{array}$ & $\begin{array}{c}\text { Randomized open } \\
\text { multi-arm parallel } \\
\text { Study. } \\
68 \text { patients (mean } \\
\text { age in GSW } \\
\text { group-41 } \pm 10.8 \\
\text { years; IT-GSW } \\
\text { group-42.2 } \pm 16 \\
\text { years; UVB } \\
\text { group-37.9 } \pm \\
14.4 \text { y) }\end{array}$ & $\begin{array}{c}\text { Severity and extent of } \\
\text { psoriasis were measured by } \\
\text { the Psoriasis Area and } \\
\text { Severity Index (PASI), } \\
\text { disease status (clear of } \\
\text { diseases/almost clear) } \\
\text { using Lattice System } \\
\text { Physician's Global } \\
\text { Assessment score at week } 6 \\
\text { and change from baseline } \\
\text { in Dermatology Life quality } \\
\text { Index (DLQI) at week } 10 .\end{array}$ & 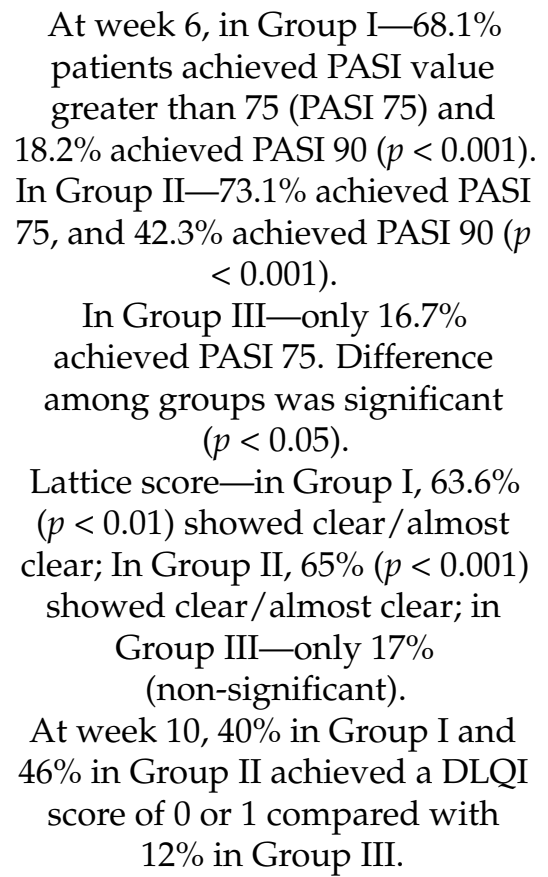 & $\begin{array}{c}\text { GA: Iceland } \\
\text { TWC: } 24^{\circ} \mathrm{C} \text { rich in } \\
\mathrm{Na}^{+}, \mathrm{Cl}^{-}, \mathrm{Ca}^{2+}, \mathrm{K}^{+}, \\
\mathrm{SO}_{4}{ }^{2-} \text {, and } \mathrm{Mg}^{2+}, \\
\mathrm{SiO}_{2}, \mathrm{~F}^{-}, \mathrm{CO}_{2} \text {, and } \\
\mathrm{H}_{2} \mathrm{~S} \text {. }\end{array}$ & {$[54]$} \\
\hline
\end{tabular}


Table 5. Cont.

\begin{tabular}{|c|c|c|c|c|c|c|}
\hline $\begin{array}{l}\text { Disease } \\
\text { Category }\end{array}$ & $\begin{array}{l}\text { Study Design and } \\
\text { Treatment Arms }\end{array}$ & $\begin{array}{c}\text { Study Type \& } \\
\text { Study Population }\end{array}$ & $\begin{array}{c}\text { Clinical Parameters } \\
\text { Examined }\end{array}$ & Outcomes of the Study & $\begin{array}{c}\text { Geographical Area } \\
\text { (GA) and Thermal } \\
\text { Water Composition } \\
\text { (TWC) }\end{array}$ & References \\
\hline Rhinitis. & $\begin{array}{l}\text { Group I }(n=34) \text { : } \\
\text { herb-infused steam bath. } \\
\text { Group II }(n=34) \text { : steam } \\
\text { bath without herbs. } \\
\text { Both groups received } \\
\text { treatment for } 30 \text { min } 3 \\
\text { times a week for } 4 \\
\text { consecutive weeks. } \\
\text { Assessment: baseline, } 1 \mathrm{w}, \\
2 \mathrm{w}, 3 \mathrm{w}, 4 \mathrm{w} . \\
\text { TM: no additional. }\end{array}$ & $\begin{array}{l}\text { A single-blind } \\
\text { randomized } \\
\text { controlled trial. } \\
68 \text { patients (20-59 } \\
\text { years age). }\end{array}$ & $\begin{array}{l}\text { Allergic rhinitis symptoms } \\
\text { (itchy nose, runny nose, } \\
\text { sneezing, nasal congestion, } \\
\text { and watery eyes) were } \\
\text { measured using the VAS at } \\
\text { week } 0,1,2,3, \text { and } 4 ; \\
\text { Quality of life was assessed } \\
\text { using questionnaires from } \\
\text { Clinical Practice Guideline } \\
\text { of Thai Traditional } \\
\text { Medicine at week } 0 \text { and } 4 .\end{array}$ & $\begin{array}{c}\text { Symptoms were significantly } \\
\text { reduced in both groups at week } 2, \\
3 \text {, and } 4 \text {, but difference was not } \\
\text { significant between two treatment } \\
\text { methods. } \\
\text { Patients' satisfaction was } \\
\text { significantly greater in Group I } \\
\text { compared to control group } \\
(p<0.05) .\end{array}$ & $\begin{array}{c}\text { GA: Bangkok, } \\
\text { Thailand. } \\
\text { TWC: herb infused } \\
\text { water. }\end{array}$ & [55] \\
\hline
\end{tabular}

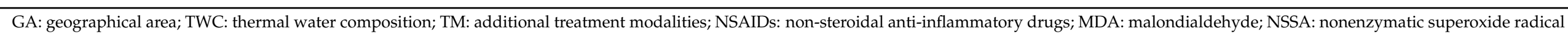
scavenger activity; AOP: antioxidant potential; SOD: superoxide dismutase. 


\section{Discussion}

\subsection{Worldwide Practices of MH Accentuating Bhutanese Perspectives}

Hydrotherapy is practiced worldwide, such as North and South America, Europe, and Asia (Thailand, Japan, Indonesia, and China) [33]. For instance, the Japanese use three main types of hydrotherapy, namely, onsen (hot spring bath), furo (bathing in a tub), and sento (public bathing), particularly onsen or Touji therapy is said to have practiced from as early as 700 B.C. [56]. Chinese herbal therapy containing 11 herbal ingredients [33] is used effectively against itching resulting from uremia [57]. In Bhutan, the $\mathrm{MH}$ is still very popular among the Bhutanese to maintain their health and treat illnesses. Moreover, herbal bath therapy (bdud-rtsi lnga-lums) is incorporated as one of the alternative treatment regimens in the mainstream BSM to treat pain, rheumatism, respiratory diseases, skin diseases, osteoarthritis, and uremic pruritus. Ladakhi Amchi (traditional physician) in India practices herbal bath therapy (bdud-rtsi lnga-lums), which is similar to that of the Bhutanese herbal therapy with slight variations in the decoction formulations [58]. This herbal bath therapy (known as 'lums medicinal bathing' in Tibetan) is also used (with slight variations in the formulations) in Tibetan medicine, and the Chinese government has recently registered this lums medicinal bathing as one of the UNESCO's Intangible Cultural Heritage in 2018 [59]. Lums medicinal bathing is very similar to the bathing culture practiced in indigenous medicine systems of India, Egypt, Europe, Russia [60], and Bhutan. Indeed, the scholarly Tibetan medicine is believed to be the hybrid of other major scholarly medicine systems such as Ayurvedic, Greco-Arabic, and Chinese traditional medicines [61]. Thus, origin, practice, development, transmission, and ownership (as cultural and knowledge property) for indigenous medical practices, including lums medicinal bathing, are very complex and controversial. Except for slight variations in the techniques and recipes used, the purpose, beliefs, and history of MH practiced worldwide are almost similar.

Balneotherapy or mineral water-based therapy is also practiced worldwide [12]. Japan has the highest number of hot springs $(27,000$ sources in 3170 locations) in the world, and according to their law (Hot Spring Law-1948), therapeutic hot spring must have a temperature not less than $25^{\circ} \mathrm{C}$ and should contain at least one out of 19 mineral components [62]. Japanese categorizes hot springs based on three parameters, namely, chemical content (consist of nine types), water temperature (consist of four types), and concentration of hydrogen ions (consist of five types) [62]. In Taiwanese culture, hot springs are of three types: sulfur-rich acidic hot spring, hydrogen carbonate-rich neutral hot spring, and chlorine-rich acidic hot spring [63]. In Bhutan, almost all hot springs are said to be rich in minerals. According to few $\mathrm{MH}$ traditional documents, including "Hot springs and mineral springs of Bhutan" [64], a classical text on Bhutan's hot springs and mineral springs [28], and Khempajong hot spring (mkhen-pa-ljong gnyes tsha-chu) [65], hot springs in Bhutan are rich in coal ( $r$ do-sol with various colors ranging from light blue, blue-black, and whitish), sulfur (mu-zi or mu-ljang), limestone (rdo-thal), mineral pitch (brag-zhun), and sodium carbonate (cong-zhi). However, there are no scientific geochemical studies conducted so far to quantify their mineral contents. The current study could classify hot springs based on only water temperature as hot-, warm-, tepid, and regular cold springs. There is an urgent need for more rigorous scientific studies on Bhutanese hot springs and mineral springs to characterize mineral compositions present in each hot spring pool.

Bathing in the hot springs and mineral springs facilitates direct adsorption of minerals, such as calcium, chlorine, fluorine, iron, magnesium, potassium, silicon dioxide, sodium, and sulfur through the skin, which in turn can treat skin conditions such as atopic dermatitis and psoriasis [66-68]. Sulfurous mineral waters have been long used in the $\mathrm{MH}$ for treating numerous diseases, and recent studies and clinical trials are showing benefits of topical application of sulfurous mineral waters and sulfurous muds (peloids) for hand and knee osteoarthritis, rheumatoid arthritis, skin diseases, chronic inflammatory diseases, and alleviating anxiety in the patients with chronic diseases such as terminal stage cancer $[36,47,52,53]$. The beneficial effect of such waters and muds (peliods) is mainly due to the presence of sulfur in the form of hydrogen sulfide $\left(\mathrm{H}_{2} \mathrm{~S}\right)$, which is formed naturally 
from organic decomposition. Sulfur compounds in the water are said to break the mucin's disulfide bonds and activate breathing and blood circulation and reduce inflammation [69]. Our body can endogenously produce small quantities of $\mathrm{H}_{2} \mathrm{~S}$, which act as a neuromodulator in the brain, and within the vasculature promotes vasodilation and growth of new vessel [70]. Moreover, $\mathrm{H}_{2} \mathrm{~S}$ is described as gasotransmitter, which functions as a signalling molecule involved in the cytoprotective functions [71]. However, exposure to $\mathrm{H}_{2} \mathrm{~S}$ at certain concentrations can be toxic equivalent to carbon dioxide and cyanide and thus it is crucial to determine the chronicity of sulfur concentrations and to define the treatment duration in the sulfurous hot springs and mineral waters.

The spiritually empowered water therapy or holy water is also prevalent in many countries, and this is captured comprehensively by the book on "Spiritual Bathing: Healing Rituals and Traditions from Around the World" [72]. Holy water or blessed water plays a central role in different religions such as Christianity, Hinduism, and Buddhism [73]. The cultural traditions may slightly differ, but their beliefs are almost similar. In Christianity, water sprinkling onto a person's forehead or immersing in the water (baptism) symbolizes purification, regeneration, and admission to the Christian Church [74]. In Hinduism, the river Ganges is considered as a goddess and divinely, and the devotees drink and undertake purification bath, as well as it is customary for the Hindus and Sikhs to scatter the ashes of the cremated bodies into the river to transport their soul to the next life [73]. In the Shintoism culture (modern sect Shinto) of Japan, the use of water in purification rituals is still prominent today [75]. In Buddhism, primarily practiced in Bhutan, at least three types of holy waters, namely, mantra-empowered or blessed water (sngags-chu), ablution water or sacred cleansing water (khrus-gsol-chu), and ambrosia from the vase (bdud-rtsi bum-chu) are distinguishable. Unlike the other two forms of spiritually empowered waters, ambrosia from the vase uses medicinal herbs, including Cinnamomum camphora and Crocus sativus. It is interesting to note here that camphor present in C. camphora possesses antiseptic, analgesic, antipruritic, counterirritant, and rubefacient properties, and the whole plant infusion is used as an inhalant treatment for cold and lung diseases [76]. C. sativus contain more than 150 compounds, including crocin, which renders yellowish-orange color to the water (bdud-rtsi bum-chu) [77]. Interestingly, yellow-orange color is linked to the color of the robes worn by spiritual masters.

Amongst three water-based therapies of Bhutan, herbal bath and balneotherapy are the most popular practices in Bhutan. These therapies heal the patients from chronic diseases and give other users an increasingly adjusted and incorporated life, helping them rejuvenate their worn-out body, restoring the psyche, and empowering the soul. The government's recent move to make them the centerpieces of eco- and health tourism, to a greater extent, embodies an idea that consolidates medical treatments, well-being, recreation, unwinding industry, and cultural excellence. While these two forms of waterbased treatments have commercial applications, there is a need to evaluate the quality and safety of herbal bath and balneotherapy in Bhutan.

\subsection{Quality, Safety and Efficacy of Medical Hydrology in Bhutan}

\subsubsection{Herbal Bath Therapy}

Herbal bath therapy is an integral part of traditional BSM health care services. We have previously described how QSE of BSM is managed and regulated under the settings of university medical education, hospital services, and pharmaceutical production processes [78]. We found that NTMH developed numerous standard guidelines and reference materials through a series of consultative workshops to provide BSM treatments with the same quality, safety, and effectiveness. These guidelines are (i) diseases codes and classification system for correctly diagnosing the diseases; (ii) standard treatment guidelines for traditional medicine; (iii) national traditional medicine professional service standards; (iv) therapy guidelines (including herbal bath therapy) for traditional medicine practitioners; (v) standard operating procedures for traditional medicine services; and (vi) guidelines for detecting, reporting, and managing adverse drug reactions [78-81]. The traditional 
physicians and clinical assistants are trained on following, operating, and using these guidelines while providing the traditional medical health care services. In a study conducted by Wangdi [82] on the efficacy of herbal bath therapy in Bhutan, 163 out of 226 patients $(72 \%)$ interviewed showed a positive response, and only 22 patients $(10 \%)$ experienced discomfort such as headache and nausea during the treatment. It is likely for this reason that herbal bath therapy is the most popular treatment availed by patients visiting NTMH in Bhutan.

\subsubsection{Balneotherapy and Clinical Trials}

Balneotherapy has been used worldwide for more than thousands of years, and it is still arguable as this practice would not have lasted that long if it were not effective. However, a long history of traditional uses cannot be taken per se as scientific proof of efficacy unless proven from a mechanistic point of view. Maintaining hygiene is critical in balneotherapy. Because thermal waters are rich in microbial organisms (both natural and introduced) [83-85], including infectious Clostridium [86] and Legionella strains [87], and cyanobacterial toxins [88], the waters can be hazardous for users $[89,90]$ if they are not appropriately managed. Cyanotoxins, such as microcystin-LR produced by an alga (Microcystis aeruginosa), which is common worldwide in drinking water reservoirs [91], is hepatoxic [92] and can cause death [93]. Mohamed [88] detected toxic cyanobacteria and cyanotoxins in the public hot springs in Saudi Arabia. It is most likely that Bhutanese hot springs may contain such toxic microbes as their water sources are freshwater and have similar physiochemical properties, including the water temperature. Contamination of hot spring by legionellae (Legionella pneumophila) is also common and was isolated from many hot springs in Japan [94], which causes Legionnaires' disease [95,96]. Such risks associated with the use of hot spring waters have led to the revision of Japanese Onsen Law in 2007 and incorporated compulsory testing for Legionella contamination every year and analysis of onsen water at source or entry to the bathtub every five years [62]. In addition to infectious and toxic microbes, hot springs also contain a considerable amount of heavy metals [97], which, if exposed to long-duration, may be adverse to human health.

Traditionally, the QSE of hot springs and mineral spring water is driven by faith and is often more inclined to adhere to strong cultural and spiritual beliefs [65]. For example, in Bhutan, appeasing the guardian deities of the hot spring and mineral spring water sites and maintaining absolute cleanliness of the water sources and pools, and their surrounding areas are the most customary practices among visitors. Before visiting hot or mineral spring sites, visitors consult an astrologer or traditional physician to determine the appropriate time of the visit and obtain specific instructions for deriving the best therapeutic benefits. Generally, the Bhutanese consider the period between the 16th-30th days of the tenth and eleventh months-in winter or of the second and third lunar months in spring Bhutanese lunar calendar year (mar-ngo tshe) as the best time to visit hot springs. They believe that there are least disturbances by other cosmo-physical elements during these periods and that the health is progressive, and the hot or mineral spring waters are empowered to yield the most effective result. Women and girls who are on their menstrual periods refrain from entering the hot spring pools. It is believed that any unhygienic activities would provoke the wrathful guardian deities, whose punishments range from sudden snowfall, downpours of rain accompanied by abnormally large hailstones, dreadful lightning, and thunder. We have previously described in detail the cultural and religious beliefs associated with balneotherapy practices elsewhere [65]. Such belief systems have shaped and helped maintain Bhutan's hot or mineral spring water sites serine and clean.

There are limited studies on the quality, safety, and efficacy of the Bhutanese hot springs and mineral spring waters. However, our literature review and the meta-analysis of the published information on balneotherapy shows that about 22 randomized clinical trials have been conducted between 2012-2019 (as shown in Table 5). The majority of the randomized clinical trials focused on osteoarthritis and general improvement of quality of life, and most of these trials were reported from Italy and Hungary. Although, bal- 
neotherapy yielded better or significant clinical improvements in patients especially with osteoarthritis compared to control groups, their mechanism of action remains unknown. Since hot springs and mineral spring water therapies are popular in Bhutan, there is urgent need for conducting clinical trials, as well as assess their adverse health implications.

\subsubsection{Spiritually Empowered Holy Waters}

Drinking spiritually-empowered holy water is common in Bhutan and other parts of the world, including Europe [98] and Japan [62], because they believe it contains curative power. A study conducted by Kirschner et al. [99] found that holy water could be underestimated sources of illness since holy water kept in hospital chapels and frequently visited churches contained pathogens such as Pseudomonas aeruginosa and Staphylococcus aureus. In Bhutan, mantra empowered water (ngag-chu), sacred cleansing water (khrue-sel$c h u)$ and herb-infused holy water (bdud-rtsi bum-chu) kept in the temples are commonly used for treating patients suffering from defilements and afflictions caused by evil spirits. Mantra empowerment is conducted by lay priests (Gomchens) or astrologers (rtsip) or Buddhist spiritual masters (bla-mas or Rinpoches) by reciting the specific mantra and blowing or whooshing the fresh tap water inside the containers. While there is no risk associated with the spiritually empowered waters, their long-term storage may likely facilitate the growth of pathogens that may cause infections in those who seek blessing via drinking or wetting their head with holy waters. It is also possible that during the act of empowerment, whooshing may produce saliva droplets that could potentially spread microbial infectious diseases (e.g., SARS-CoV-2 and tuberculosis) if a person who is conducting water empowerment has the infection.

\section{Conclusions and Future Directions}

Medical hydrology or hydrotherapy in Bhutan still holds a firm position as an alternative healing option, for the country is rich in herbal and mineral water resources with curative and therapeutic benefits. Out of three types of $\mathrm{MH}$ practiced in Bhutan, herbal bath and balneotherapy have greater potential for applications in health care and eco-health tourism. This study identified four types of herbal bath therapies, ten hot springs, 17 mineral springs, and 17 holy spring-waters in Bhutan. While the traditional physicians prescribe herbal bath therapies, and the treatments are done within the hospital or health care facilities, balneotherapy is an open-access resource commonly used by the people without consultation. Although herbal bath and balneotherapy are both claimed to be effective against chronic diseases such as arthritis, rheumatism, musculoskeletal and neurological disorders, urinary tract infection, and dermatological diseases; their efficacy remains anecdotal without proper documentation of the clinical data. Therapeutic claims of all forms of MH need to be substantiated through clinical studies, and we believe that it can be done using appropriate methodologies described by other international researchers, whose works we have discussed earlier in this study. Collecting scientific or clinical works on balneotherapy that has already been carried out by international researchers and societies would improve the education level and overall knowledge of the traditional Bhutanese physicians. This would help foster better collaborations between researchers in Bhutan and abroad. Such collaborations would improve the quality and trigger number of clinical trials and the medical standards of MH in Bhutan. Future works are required in the following areas:

- Conducting randomized clinical studies on four herbal bath therapies currently offered by the NTMH, Thimphu.

- Determining the $\mathrm{pH}$, microbiological composition, and chemical compositions of all hot springs and mineral springs and develop a comprehensive monograph for geothermal resources in the country.

- Conducting correlational studies between their chemical compositions and traditionally claimed health benefits. 
- Formulating an appropriate law and regulations, including compulsory water quality testing of hot springs and mineral springs.

Supplementary Materials: The following are available online at https://www.mdpi.com/2073-444 1/13/1/9/s1, Table S1: Transliterated Sowa Rigpa terms.

Author Contributions: Conceptualization, P.W. and K.Y.; methodology, P.W. and K.Y.; software, P.W. and K.Y.; validation, P.W., K.Y., and K.U.; formal analysis, P.W., K.Y., and K.U.; investigation, P.W., K.Y., J.D., S., P.T. and K.W.; resources, P.W., K.Y., K.U., K.W., S., P.T. and J.D.; data curation, P.W. and K.Y.; writing—original draft preparation, P.W. and K.Y.; writing—review and editing, P.W., A.S.N and K.U.; project administration, P.W. and K.Y.; funding acquisition, P.W.; All authors have read and agreed to the published version of the manuscript.

Funding: This research has been carried out through small grants provided by World Health Organization for documenting the balneotherapy in Bhutan.

Acknowledgments: We are immensely grateful to Katharina Sabernig, Institute for Social Anthropology, Austrian Academy of Sciences, Vienna, Austria, for helping us verify the accuracy of transliterated Sowa Rigpa terminologies and proofreading the manuscript. We appreciate Gups (head of administrative blocks) and Tshogpas (village representatives) who helped us with administrative works during the fieldwork. All the study participants, including traditional physicians and clinicians, made invaluable contributions through sharing their views, opinions, historical backgrounds, and ethnopharmacological knowledge about hot springs and mineral springs included in this study. We are also thankful to Drungtsho Gembo Dorji, Drungtsho Kunzang Dorji, Drungtsho Yeshi Dorji, Sonam Dorji, and Tashi, for surveying some hot springs in Bhutan.

Conflicts of Interest: The authors declare that we have no conflict of interest in this study.

\section{References}

1. Blake, E. Naturopathic hydrotherapy in the treatment of fibromyalgia. Fibromyalgia Syndr. 2010, 289-302. [CrossRef]

2. Cesarz, T.; Speach, D. Aquatic Physical Therapy. In The Comprehensive Treatment of the Aging Spine; Elsevier BV: Radarweg, Amsterdam, The Netherlands, 2011; pp. 103-104.

3. Verhagen, A.P.; Bierma-Zeinstra, S.M.; Boers, M.; Cardoso, J.R.; Lambeck, J.; De Bie, R.; De Vet, H.C. Balneotherapy (or spa therapy) for rheumatoid arthritis. An abridged version of Cochrane Systematic Review. Eur. J. Phys. Rehabil. Med. 2015, 51, 1-50.

4. Davinelli, S.; Bassetto, F.; Vitale, M.; Scapagnini, G. Thermal Waters and the Hormetic Effects of Hydrogen Sulfide on Inflammatory Arthritis and Wound Healing. In The Science of Hormesis in Health and Longevity; Elsevier BV: Radarweg, Amsterdam, The Netherlands, 2019; pp. 121-126.

5. Pittler, M.H.; Ernst, E.; Karagülle, M.Z.; Karagülle, M. Spa therapy and balneotherapy for treating low back pain: Meta-analysis of randomized trials. Rheumatology 2006, 45, 880-884. [CrossRef] [PubMed]

6. Pesce, A. Thermal Spas: An Economic Development Alternative along Both Sides of the Uruguay River. Available online: https: / / citeseerx.ist.psu.edu/viewdoc/download?doi=10.1.1.483.5345\&rep=rep1\&type=pdf (accessed on 4 September 2020).

7. Bahadorfar, M. A study of hydrotherapy and its health benefits. Int. J. Res. 2014, 8, 294-305.

8. Tsitsis, N.; Polkas, G.; Daoutis, A.; Prokooiou, E.; Kourkouta, L. Hydrotherapy in Ancient Greece. Balk. Mil. Med. Rev. 2013, $16,462-466$.

9. Jackson, R. Waters and spas in the classical world. Med. Hist. 1990, 34, 1-13. [CrossRef]

10. Gianfaldoni, S.; Tchernev, G.; Wollina, U.; Roccia, M.G.; Fioranelli, M.; Gianfaldoni, R.; Lotti, T. History of the Baths and Thermal Medicine. Open Access Maced. J. Med. Sci. 2017, 5, 566-568. [CrossRef]

11. Ablin, J.J.; Häuser, W.; Buskila, D. Spa Treatment (Balneotherapy) for Fibromyalgia-A Qualitative-Narrative Review and a Historical Perspective. Evid. Based Complement. Altern. Med. 2013, 2013, 1-5. [CrossRef]

12. Matz, H.; Orion, E.; Wolf, R. Balneotherapy in dermatology. Dermatol. Ther. 2003, 16, 132-140. [CrossRef]

13. Gonpo, Y.Y. The Subsequent Tantra from the Secret Quintessential Instructions on the Eight Branches of the Ambrosia Essence Tantra; Men-Tsee-Khang Publications: Dharamsala, India, 2011.

14. Gonpo, Y.Y. The Root Tantra and the Explanatory from the Secret Quintessential Instructions on the Eight Branches of the Ambrosia Essence Tantra; Men-Tsee-Khang Publications: Daramsala, India, 2011.

15. Yuri, P.; Dorje, G.; Meyer, F. Tibetan Medical Paintings: Illustrations to the 'Blue Beryl' Treatise of Sangs Rgyas Rgya Mtsho; Serindia Publications: London, UK, 1992; pp. 1653-1705.

16. Yonten, P. External Therapies in Tibetan Medicine: The Four Tantras, Contemporary Practice, and a Preliminary History of Surgery. In Bodies in Balance-The Art of Tibetan Medicine; Theresia, H., Ed.; Rubin Museum of Art and University of Washington Press: New York, NY, USA, 2014; pp. 64-89. 
17. Katharina, S. Kalte Kräuter und heiße Bäder: Die Anwendung der Tibetischen Medizin in den Köstern Amdos. In Wiener Ethnomedizinische Reihe: Band 5; Lit.: Wien, Austria, 2007.

18. Katharina, S. External Treatments at Kumbum Monastery Hospital. Vienn. Ethnomedicine Newsl. 2005, 7, 7-15.

19. Wangchuk, P.; Pyne, S.G.; Keller, P.A. An assessment of the Bhutanese traditional medicine for its ethnopharmacology, ethnobotany and ethnoquality: Textual understanding and the current practices. J. Ethnopharmacol. 2013, 148, 305-310. [CrossRef] [PubMed]

20. Wangchuk, P.; Yeshi, K.; Jamphel, K. Pharmacological, ethnopharmacological, and botanical evaluation of subtropical medicinal plants of Lower Kheng region in Bhutan. Integr. Med. Res. 2017, 6, 372-387. [CrossRef]

21. Wangchuk, P.; Namgay, K.; Gayleg, K.; Dorji, Y. Medicinal plants of Dagala region in Bhutan: Their diversity, distribution, uses and economic potential. J. Ethnobiol. Ethnomed. 2016, 12, 1-18. [CrossRef] [PubMed]

22. Yeshi, K.; Gyal, Y.; Sabernig, K.; Phuntsho, J.; Tidwell, T.; Jamtsho, T.; Dhondup, R.; Tokar, E.; Wangchuk, P. An integrated medicine of Bhutan: Sowa Rigpa concepts, botanical identification, and the recorded phytochemical and pharmacological properties of the eastern Himalayan medicinal plants. Eur. J. Integr. Med. 2019, 29, 1-15. [CrossRef]

23. Yeshi, K.; Morisco, P.; Wangchuk, P. Animal-derived natural products of Sowa Rigpa medicine: Their pharmacopoeial description, current utilization and zoological identification. J. Ethnopharmacol. 2017, 207, 192-202. [CrossRef] [PubMed]

24. Yeshi, K.; Wangdi, T.; Qusar, N.; Nettles, J.; Craig, S.R.; Schrempf, M.; Wangchuk, P. Geopharmaceuticals of Himalayan Sowa Rigpa medicine: Ethnopharmacological uses, mineral diversity, chemical identification and current utilization in Bhutan. J. Ethnopharmacol. 2018, 223, 99-112. [CrossRef]

25. Wangchuk, P.; Pyne, S.G.; Keller, P.A. Ethnobotanical authentication and identification of Khrog-sman (Lower Elevation Medicinal Plants) of Bhutan. J. Ethnopharmacol. 2011, 134, 813-823. [CrossRef] [PubMed]

26. Phuntshok. Shel-Gong-Shel-Phreng; T.M.A.I. Publishers: Dharamsala, Himachal Pradesh, India, 1994.

27. Dorje, G. Khrungs-d.pe-dri-med-shel-gyi-me-long (Immaculate Crystal Mirror of Materia Medica Illustrations); Mi Rigs Dpe Skrun Khang: Beijing, China, 1995.

28. Dorji, Y. 'Brug-Gi Tshachu Dang Smanchu Rnam-Bshad 'Chi-Med Bdud-Rtsi'i Bum-Bzang. 'Brug Nang Sman Zhib-'Tshol Dang Gong-'Phel Tshogs-pa; Nang-pa'i Gso-Rig 'Bzin-Skyong-lte-ba; Institute of Traditional Medicine Services: Thimphu, Bhutan, 2008.

29. Pentecost, A. Hot springs, thermal springs and warm springs. What's the difference? Geol. Today 2005, 21, 222-224. [CrossRef]

30. Pentecost, A.; Jones, B.; Renaut, R.W. What is a hot spring? Can. J. Earth Sci. 2003, 40, 1443-1446. [CrossRef]

31. Phuntsho, K. Thruebab, the Descent of Blessed Water. Kuenselonline (National Newspaper). Available online: https: / / kuenselonline. com/trhuebab-the-descent-of-blessed-water/ (accessed on 4 September 2020).

32. Falagas, M.E.; Zarkadoulia, E.; Rafailidis, P.I. The therapeutic effect of balneotherapy: Evaluation of the evidence from randomised controlled trials. Int. J. Clin. Pract. 2009, 63, 1068-1084. [CrossRef]

33. Xue, W.; Zhao, Y.; Yuan, M.; Zhao, Z. Chinese herbal bath therapy for the treatment of uremic pruritus: Meta-analysis of randomized controlled trials. BMC Complement. Altern. Med. 2019, 19, 103. [CrossRef]

34. Fioravanti, A.; Giannitti, C.; Bellisai, B.; Iacoponi, F.; Galeazzi, M. Efficacy of balneotherapy on pain, function and quality of life in patients with osteoarthritis of the knee. Int. J. Biometeorol. 2011, 56, 583-590. [CrossRef]

35. Goto, Y.; Hayasaka, S.; Kurihara, S.; Nakamura, Y. Physical and Mental Effects of Bathing: A Randomized Intervention Study. Evid. Based Complement. Altern. Med. 2018, 2018, 9521086. [CrossRef]

36. Fujimoto, S.; Iwawaki, Y.; Takishita, Y.; Yamamoto, Y.; Murota, M.; Yoshioka, S.; Hayano, A.; Hosokawa, T.; Yamanaka, R. Effects and safety of mechanical bathing as a complementary therapy for terminal stage cancer patients from the physiological and psychological perspective: A pilot study. Jpn. J. Clin. Oncol. 2017, 47, 1066-1072. [CrossRef]

37. Naumann, J.; Grebe, J.; Kaifel, S.; Weinert, T.; Sadaghiani, C.; Huber, R. Effects of hyperthermic baths on depression, sleep and heart rate variability in patients with depressive disorder: A randomized clinical pilot trial. BMC Complement. Altern. Med. 2017, 17, 172. [CrossRef]

38. Stier-Jarmer, M.; Frisch, D.; Oberhauser, C.; Immich, G.; Kirschneck, M.; Schuh, A. Effects of single moor baths on physiological stress response and psychological state: A pilot study. Int. J. Biometeorol. 2017, 61, 1957-1964. [CrossRef]

39. Yang, B.; Lin, J.; Qin, Q.-Z.; Han, L.-L.; Chen, Y. Spa therapy (balneotherapy) relieves mental stress, sleep disorder, and general health problems in sub-healthy people. Int. J. Biometeorol. 2017, 62, 261-272. [CrossRef]

40. Rapolienè, L.; Razbadauskas, A.; Jurgelènas, A. The Reduction of Distress Using Therapeutic Geothermal Water Procedures in a Randomized Controlled Clinical Trial. Adv. Prev. Med. 2015, 2015, 749417. [CrossRef]

41. Rapolienè, L.; Razbadauskas, A.; Salyga, J.; Martinkènas, A. Stress and Fatigue Management Using Balneotherapy in a Short-Time Randomized Controlled Trial. Evid. Based Complement. Altern. Med. 2016, 2016, 9631684. [CrossRef]

42. Özkuk, K.; Gürdal, H.; Karagülle, M.; Barut, Y.; Eröksüz, R.; Karagülle, M.Z. Balneological outpatient treatment for patients with knee osteoarthritis; an effective non-drug therapy option in daily routine? Int. J. Biometeorol. 2016, 61, 719-728. [CrossRef]

43. Genç, A.; Celik, S.U.; Evcik, D.; Atman, E.D.; Elhan, A.H.; Genc, V. Balneotherapy is an alternative treatment for mastalgia; a randomized controlled trial. Eur. J. Integr. Med. 2018, 19, 100-104. [CrossRef]

44. Min, K.-J.; Choi, H.; Tae, B.S.; Lee, M.-G.; Lee, S.J.; Hong, K.D. Short-term benefits of balneotherapy for patients with chronic pelvic pain: A pilot study in Korea. J. Obstet. Gynaecol. 2019, 40, 520-525. [CrossRef]

45. Fioravanti, A.; Manica, P.; Bortolotti, R.; Cevenini, G.; Tenti, S.; Paolazzi, G. Is balneotherapy effective for fibromyalgia? Results from a 6-month double-blind randomized clinical trial. Clin. Rheumatol. 2018, 37, 2203-2212. [CrossRef] 
46. Hanzel, A.; Horvát, K.; Molics, B.; Berényi, K.; Németh, B.; Szendi, K.; Varga, C. Clinical improvement of patients with osteoarthritis using thermal mineral water at Szigetvár Spa-results of a randomised double-blind controlled study. Int. J. Biometeorol. 2017, 62, 253-259. [CrossRef]

47. Karagülle, M.; Kardeş, S.; Karagülle, O.; Dişçi, R.; Avc1, A.; Durak, I.; Karagülle, M.Z. Effect of spa therapy with saline balneotherapy on oxidant/antioxidant status in patients with rheumatoid arthritis: A single-blind randomized controlled trial. Int. J. Biometeorol. 2016, 61, 169-180. [CrossRef]

48. Gáti, T.; Tefner, I.K.; Kovács, L.; Hodosi, K.; Bender, T. The effects of the calcium-magnesium-bicarbonate content in thermal mineral water on chronic low back pain: A randomized, controlled follow-up study. Int. J. Biometeorol. 2018, 62, 897-905. [CrossRef]

49. Masiero, S.; Vittadini, F.; Ferroni, C.; Bosco, A.; Serra, R.; Frigo, A.C.; Frizziero, A. The role of thermal balneotherapy in the treatment of obese patient with knee osteoarthritis. Int. J. Biometeorol. 2018, 62, 243-252. [CrossRef]

50. Şahin-Onat, Ş.; Taşoğlu, Ö.; Özişler, Z.; Güneri, F.D.; Özgirgin, N. Balneotherapy in the Treatment of Knee Osteoarthritis: A Controlled Study. Arch. Rheumatol. 2015, 30, 292-297. [CrossRef]

51. Bazzichi, L.; Da Valle, Y.; Rossi, A.; Giacomelli, C.; Sernissi, F.; Giannaccini, G.; Betti, L.; Ciregia, F.; Giusti, L.L.; Scarpellini, P.; et al. A multidisciplinary approach to study the effects of balneotherapy and mud-bath therapy treatments on fibromyalgia. Clin. Exp. Rheumatol. 2013, 31, 111-120.

52. Hanzel, A.; Berényi, K.; Horváth, K.; Szendi, K.; Németh, B.; Varga, C. Evidence for the therapeutic effect of the organic content in Szigetvár thermal water on osteoarthritis: A double-blind, randomized, controlled clinical trial. Int. J. Biometeorol. 2019, 63, 449-458. [CrossRef]

53. Péter, I.; Jagicza, A.; Ajtay, Z.; Boncz, I.; Kiss, I.; Szendi, K.; Kustán, P.; Németh, B. Balneotherapy in Psoriasis Rehabilitation. In Vivo 2017, 31, 1163-1168. [CrossRef]

54. Eysteinsdóttir, J.H.; Ólafsson, J.H.; Agnarsson, B.A.; Lúðvíksson, B.R.; Sigurgeirsson, B. Psoriasis treatment: Faster and longstanding results after bathing in geothermal seawater. A randomized trial of three UVB phototherapy regimens. Photodermatol. Photoimmunol. Photomed. 2013, 30, 25-34. [CrossRef]

55. Tungsukruthai, P.; Nootim, P.; Worakunphanich, W.; Tabtong, N. Efficacy and safety of herbal steam bath in allergic rhinitis: A randomized controlled trial. J. Integr. Med. 2018, 16, 39-44. [CrossRef]

56. Merry, A.M. More than a bath: An examination of Japanese bathing culture. CMC Sr. Theses 2013, 665. Available online: http:/ / scholarship.claremont.edu/cmc_theses / 665 (accessed on 23 November 2020).

57. Wojcikowski, K.; Johnson, D.W.; Gobe, G. Herbs or natural substances as complementary therapies for chronic kidney disease: Ideas for future studies. J. Lab. Clin. Med. 2006, 147, 160-166. [CrossRef]

58. Adhikari, B.S.; Rawat, G.S.; Desk, S. Sowa-Rigpa: A Healthcare Practice in Trans-Himalayan Region of Ladakh, India. SDRP J. Plant Sci. 2017, 2, 621-630. [CrossRef]

59. Yi, Y. China's Lum Medicinal Bathing of Sowa Rigpa Listed as Intangible Cultural Heritage. 2018. Available online: http: //www.xinhuanet.com/english/2018-11/28/c_137637836.htm (accessed on 22 December 2020).

60. Fleming, S.A.; Gutknecht, N.C. Naturopathy and the Primary Care Practice. Prim. Care Clin. Off. Pract. 2010, 37, 119-136. [CrossRef]

61. Madhavan, H. Below the radar innovations and emerging property right approaches in Tibetan medicine. J. World Intellect. Prop. 2017, 20, 239-257. [CrossRef]

62. Serbulea, M.; Payyappallimana, U. Onsen (hot springs) in Japan-Transforming terrain into healing landscapes. Health Place 2012, 18, 1366-1373. [CrossRef]

63. Liu, C.-M.; Song, S.-R.; Chen, Y.-L.; Tsao, S. Characteristics and Origins of Hot Springs in the Tatun Volcano Group in Northern Taiwan. Terr. Atmos. Ocean. Sci. 2011, 22, 475. [CrossRef]

64. Wangdi, N.; Dorji, T.; Wangdi, K. Hotsprings and Mineral Springs of Bhutan; UWICE Press: Lamai Goempa, Bumthang, Bhutan, 2014.

65. Wangchuk, P.; Dorji, Y. Historical Roots, Spiritual Significance and the Health Benefits of mkhempa-ljong gnyes Tshachu in Lhuentse. J. Bhutan Stud. 2007, 16, 112-127.

66. Boer, J. The influence of mineral water solutions in phototherapy. Clin. Dermatol. 1996, 14, 665-673. [CrossRef]

67. Carbajo, J.M.; Maraver, F. Sulphurous mineral waters: New applications for health. Evid. Based Complement. Alternat. Med. 2017, 2017, 8034084. [CrossRef]

68. Wolf, R. Mineral water and spas in Israel. Clin. Dermatol. 1996, 14, 619-626. [CrossRef]

69. Szabó, C. Hydrogen sulphide and its therapeutic potential. Nat. Rev. Drug Discov. 2007, 6, 917-935. [CrossRef]

70. Abe, K.; Kimura, H. The possible role of hydrogen sulfide as an endogenous neuromodulator. J. Neurosci. 1996, 16, 1066-1071. [CrossRef]

71. Kimura, H. Hydrogen Sulfide and Polysulfides as Biological Mediators. Molecules 2014, 19, 16146-16157. [CrossRef]

72. Arvigo, R.; Epstein, N. Spiritual Bathing: Healing Rituals and Traditions from around the World; Celestial Arts: Berkely, CA, USA, 2003.

73. Oestigaard, T. Holy water: The works of water in defining and understanding holiness. Wiley Interdiscip. Rev. Water 2017, 4, e1205. [CrossRef]

74. Battle, J.A. The significance of the mode of baptism. WRS J. 2007, 14, 9-20. 
75. Hara, K. Aspects of Shinto in Japanese Communication. Intercult. Commun. Stud. 2003, 12, 81-103.

76. Singh, R.; Jawaid, T. Cinnamomum camphora (Kapur): Review. Pharmacogn. J. 2012, 4, 1-5. [CrossRef]

77. Mzabri, I.; Addi, M.; Berrichi, A. Addi Traditional and Modern Uses of Saffron (Crocus Sativus). Cosmetics 2019, 6, 63. [CrossRef]

78. Wangchuk, P. Tashi Quality assurance of the university medical education, hospital services and traditional pharmaceutical products of the Bhutanese So-wa-rig-pa health care system. BMC Complement. Altern. Med. 2016, 16, 283. [CrossRef]

79. MoH. Manual on Traditional Medicine Information Management System; National Traditional Medicine Hospital, Department of Medical Services, Ministry of health (MoH): Kawa Jangsa, Thimphu, Bhutan, 2010.

80. MoH. Standard Operating Procedures for Traditional Medicine Services; National Traditional Medicine Hospital, Traditional Medicine Division (DMS), Ministry of Health: Thimphu, Bhutan, 2012.

81. MoH. Collaborative Referral Guideline on Mental Health Care Services; Division of Local Healing and Spiritual Health, Department of Traditional Medicine Services, Ministry of Health: Thimphu, Bhutan, 2016.

82. Wangdi, S. An enquiry into the efficacy of Dutsi-nga-lum, a unique healing therapy in the Traditional Bhutanese Medicine. sMen-jong gSo-rig J. 2015, 7, 1-6. Available online: http://www.ftm.edu.bt/wp-content/uploads/docs/English\%20Journals/ Perceived\%20benefits\%20of\%20dutsi-nga-lum.pdf (accessed on 22 December 2020).

83. Li, L.; Ma, Z. (Sam) Global Microbiome Diversity Scaling in Hot Springs with DAR (Diversity-Area Relationship) Profiles. Front. Microbiol. 2019, 10, 118. [CrossRef]

84. Roy, C.; Rameez, M.J.; Haldar, P.K.; Peketi, A.; Mondal, N.; Bakshi, U.; Mapder, T.; Pyne, P.; Fernandes, S.; Bhattacharya, S.; et al Microbiome and ecology of a hot spring-microbialite system on the Trans-Himalayan Plateau. Sci. Rep. 2020, 10, 1-22. [CrossRef]

85. Aburto, A.; Shahsavari, E.; Cohen, M.; Mantri, N.; Ball, A.S. Analysis of the Microbiome (Bathing Biome) in Geothermal Waters from an Australian Balneotherapy Centre. Water 2020, 12, 1705. [CrossRef]

86. Ghilamicael, A.M.; Boga, H.I.; Anami, S.E.; Mehari, T.; Budambula, N.L.M. Potential human pathogenic bacteria in five hot springs in Eritrea revealed by next generation sequencing. PLoS ONE 2018, 13, e0194554. [CrossRef]

87. Sheehan, K.B.; Henson, J.M.; Ferris, M.J. Legionella Species Diversity in an Acidic Biofilm Community in Yellowstone National Park. Appl. Environ. Microbiol. 2005, 71, 507-511. [CrossRef]

88. Mohamed, Z.A. Toxic cyanobacteria and cyanotoxins in public hot springs in Saudi Arabia. Toxicon 2008, 51, 17-27. [CrossRef]

89. Amin, A.; Ahmed, I.; Salam, N.; Kim, B.-Y.; Singh, D.; Zhi, X.-Y.; Xiao, M.; Li, W.-J. Diversity and Distribution of Thermophilic Bacteria in Hot Springs of Pakistan. Microb. Ecol. 2017, 74, 116-127. [CrossRef] [PubMed]

90. Valeriani, F.; Margarucci, L.M.; Spica, V.R. Recreational Use of Spa Thermal Waters: Criticisms and Perspectives for Innovative Treatments. Int. J. Environ. Res. Public Health 2018, 15, 2675. [CrossRef] [PubMed]

91. Benson, J.M.; Hutt, J.A.; Rein, K.; Boggs, S.E.; Barr, E.B.; Fleming, L.E. The toxicity of microcystin LR in mice following 7 days of inhalation exposure. Toxicon 2005, 45, 691-698. [CrossRef] [PubMed]

92. Dawson, R. the toxicology of microcystins. Toxicon 1998, 36, 953-962. [CrossRef]

93. Carmichael, W.W.; Azevedo, S.M.; An, J.S.; Molica, R.J.; Jochimsen, E.M.; Lau, S.; Rinehart, K.L.; Shaw, G.R.; Eaglesham, G.K. Human fatalities from cyanobacteria: Chemical and biological evidence for cyanotoxins. Environ. Health Perspect 2001, 109, 663-668. [CrossRef] [PubMed]

94. Yabuuchi, E.; Wang, L.; Arakawa, M.; Yano, I. Distribution of Legionellae in Hot Spring Bath Water in Japan. Kansenshogaku Zasshi 1994, 68, 549-551. [CrossRef] [PubMed]

95. Ohno, A.; Kato, N.; Yamada, K.; Yamaguchi, K. Factors Influencing Survival of Legionella pneumophila Serotype 1 in Hot Spring Water and Tap Water. Appl. Environ. Microbiol. 2003, 69, 2540-2547. [CrossRef]

96. Kuroki, T.; Amemura-Maekawa, J.; Ohya, H.; Furukawa, I.; Suzuki, M.; Masaoka, T.; Aikawa, K.; Hibi, K.; Morita, M.; Lee, K.-I.; et al. Outbreak of Legionnaire's Disease Caused by Legionella pneumophila Serogroups 1 and 13. Emerg. Infect. Dis. 2017, 23, 349-351. [CrossRef]

97. Shakhatreh, M.A.K.; Jacob, J.H.; Hussein, E.; Masadeh, M.M.; Obeidat, S.M.; Juhmani, A.-S.F.; Al-Razaq, M.A.A. Microbiological analysis, antimicrobial activity, and heavy-metals content of Jordanian Ma'in hot-springs water. J. Infect. Public Health 2017, 10, 789-793. [CrossRef]

98. Nocco, P.B. Mineralwasser als Heilmittel [Mineral water as a cure]. Veroff. Schweiz. Ges. Gesch. Pharm. 2008, $29,13-402$.

99. Kirschner, A.; Atteneder, M.; Schmidhuber, A.; Knetsch, S.; Farnleitner, A.H.; Sommer, R. Holy springs and holy water: Underestimated sources of illness? J. Water Health 2012, 10, 349-357. [CrossRef] [PubMed] 